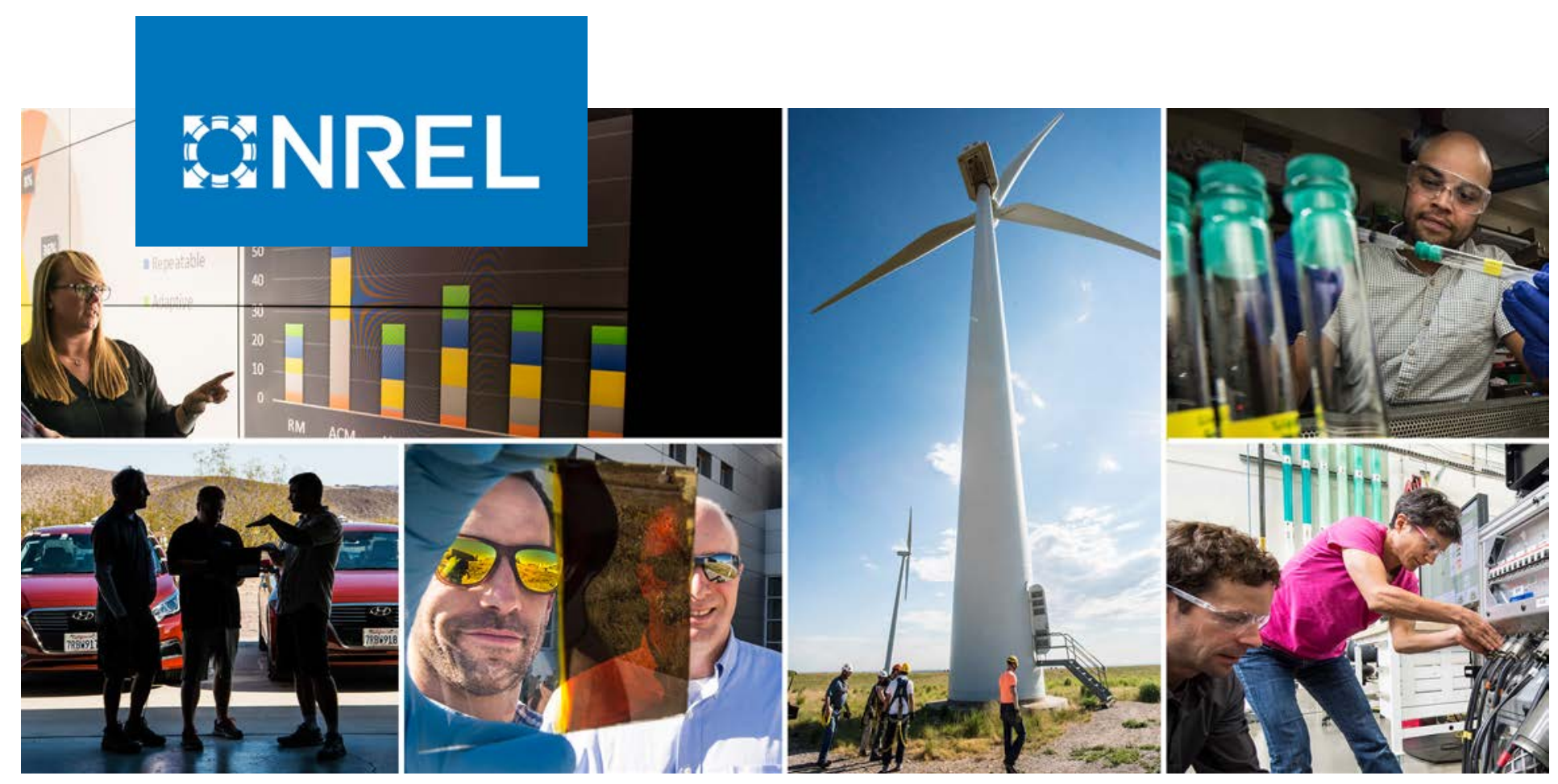

\title{
Trends in Installer Strategy and Customer Choice on a Solar PV Financing Platform
}

Jennifer Sauer, ${ }^{1,2}$ Jingwei Meng, ${ }^{1}$ and Eric O'Shaughnessy ${ }^{2}$

1 University of Texas, Austin

2 National Renewable Energy Laboratory

NREL is a national laboratory of the U.S. Department of Energy

Office of Energy Efficiency \& Renewable Energy

Operated by the Alliance for Sustainable Energy, LLC

This report is available at no cost from the National Renewable Energy Laboratory (NREL) at www.nrel.gov/publications.

\section{Technical Report}

NREL/TP-6A20-72173

December 2018 


\title{
GNREL
}

\section{Trends in Installer Strategy and Customer Choice on a Solar PV Financing Platform}

\author{
Jennifer Sauer, ${ }^{1,2}$ Jingwei Meng, ${ }^{1}$ \\ and Eric O'Shaughnessy²
}

1 University of Texas, Austin

2 National Renewable Energy Laboratory

\section{Suggested Citation}

Sauer, Jennifer, Jingwei Meng, and Eric O'Shaughnessy. 2018. Trends in Installer Strategy and Customer Choice on a Solar PV Financing Platform. Golden, CO: National Renewable Energy Laboratory. NREL/TP-6A20-72173.

https://www.nrel.gov/docs/fy19osti/72173.pdf.

NREL is a national laboratory of the U.S. Department of Energy Office of Energy Efficiency \& Renewable Energy Operated by the Alliance for Sustainable Energy, LLC

This report is available at no cost from the National Renewable Energy Laboratory (NREL) at www.nrel.gov/publications.

Contract No. DE-AC36-08GO28308
Technical Report NREL/TP-6A20-72173

December 2018

National Renewable Energy Laboratory 15013 Denver West Parkway Golden, CO 80401

303-275-3000 • www.nrel.gov 


\section{NOTICE}

This work was authored in part by the National Renewable Energy Laboratory, operated by Alliance for Sustainable Energy, LLC, for the U.S. Department of Energy (DOE) under Contract No. DE-AC36-08G028308. Funding provided by U.S. Department of Energy Office of Energy Efficiency and Renewable Energy Solar Energy Technologies Office. The views expressed herein do not necessarily represent the views of the DOE or the U.S. Government.

This report is available at no cost from the National Renewable Energy Laboratory (NREL) at www.nrel.gov/publications.

U.S. Department of Energy (DOE) reports produced after 1991 and a growing number of pre-1991 documents are available free via www.OSTI.gov.

Cover Photos by Dennis Schroeder: (clockwise, left to right) NREL 51934, NREL 45897, NREL 42160, NREL 45891, NREL 48097, NREL 46526.

NREL prints on paper that contains recycled content. 


\section{Acknowledgments}

This work was supported by the Solar Energy Technologies Office of the U.S. Department of Energy. The authors would like to thank Ariane Beck (University of Texas at Austin), Easan Drury (Braggawatt), and Paul Schwabe (NREL) for their thoughtful review of this work. We thank the University of Texas at Austin for collaborating with NREL on this project, especially Varun Rai and Cale Reeves, as well as Ryan Wiser of Lawrence Berkeley National Laboratory for overseeing the collaboration. Finally, we thank Mike Meshek (NREL) and Jarett Zuboy (consultant) for editorial support. 


\section{Executive Summary}

In the past decade, the residential solar photovoltaic (PV) industry has developed various products enabling customers to choose how to procure PV. One key innovation is the third-party ownership (TPO) model, which allows customers to purchase PV system output from a thirdparty owner rather than buy a PV system outright. TPO customers can sign a lease and make ongoing payments, sign a power-purchase agreement (PPA) and make volumetric ( $\$ / \mathrm{kWh})$ payments, or buy a prepaid product by making an upfront payment for system output.

In this study, we explore how PV installer strategies have changed over time with respect to these products and how these strategies affect PV customer choice. We use a novel data set obtained from a software platform that connects installers to institutional investors and helps installers generate TPO quotes. This data set enables us to explore the behaviors of small and mid-scale installers, whose market strategies have largely been unknown owing to lack of data. The following are key findings.

The financing platform facilitates access to financing for smaller installers, who otherwise generally cannot offer TPO. Our data set of nearly 600,000 installation quotes made on the platform from 2012 to 2016 illuminates financing product trends among more than 1,700 installers in 10 state markets.

Nationally, small and mid-scale installers shifted away from cash, prepaid, and lease offers and toward PPAs (Figure ES-1). PPA offerings increased on the platform, even in 2016 when national-scale installers decreased their PPA offerings, which suggests that small and mid-scale PV installers may provide customers with ongoing access to TPO options while large firms shift toward cash and loan strategies.

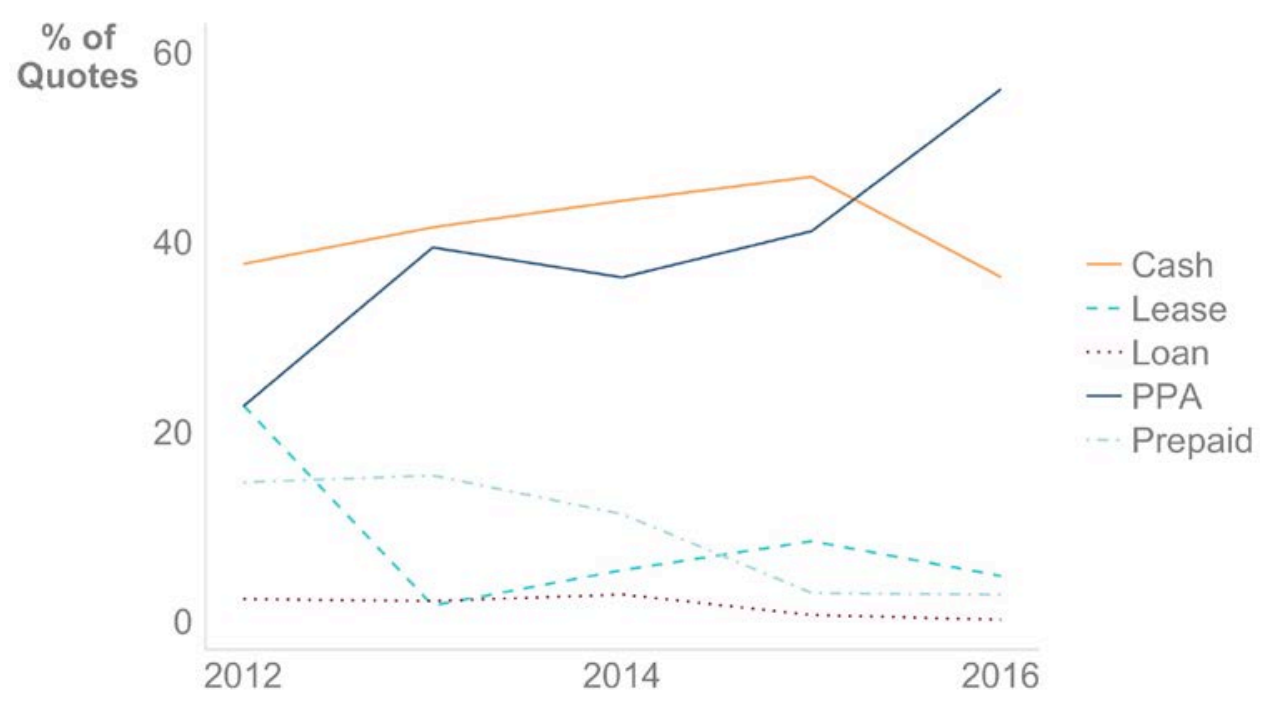

Figure ES-1. Percentage of quotes on the platform using different product types 
Policy and market drivers appeared to influence the product portfolios of the platform's installers. In several states, installers apparently modified their portfolios in response to state policy and market changes that favored some financing products over others. In addition, the platform's installers followed or deviated from trends set by national-scale installers or publicly supported PV-financing programs in some states. These product portfolio changes affected customer choice.

\section{Incumbent installer "lock in" to product offerings may limit customer choice, while} installer turnover may expand choice. The platform requires its installer partners to invest in training programs to sell specific financing products in specific states. As new installers enter a market, they may make this investment to provide financing products that align with current policy and market conditions. However, incumbent installers may hesitate to make additional investments once they have established their niche. This finding suggests that customers in regions with primarily static incumbent installers may have less access to market-aligned finance options than customers in regions with frequent installer turnover. 


\section{Table of Contents}

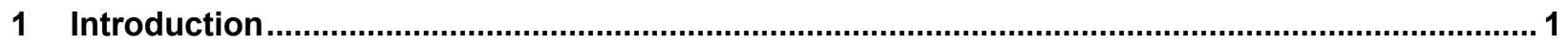

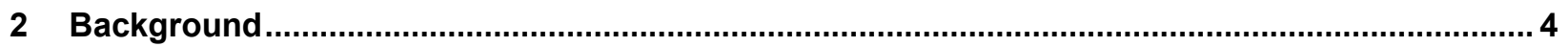

2.1 Customer Choice: PV Financing Products ......................................................................... 4

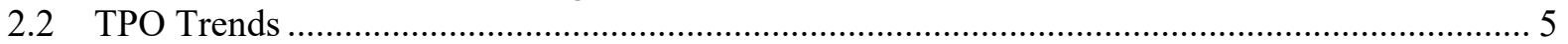

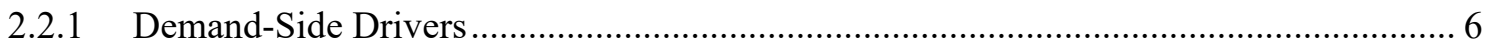

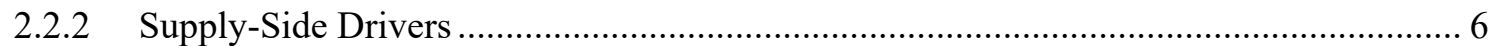

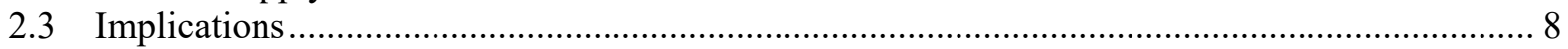

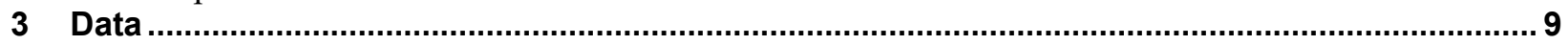

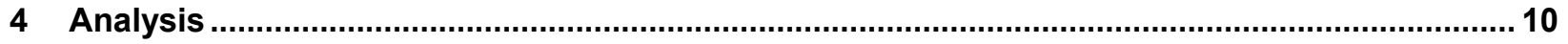

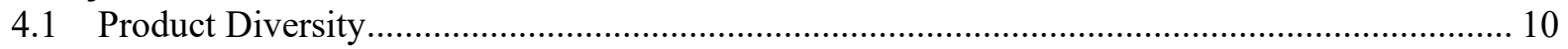

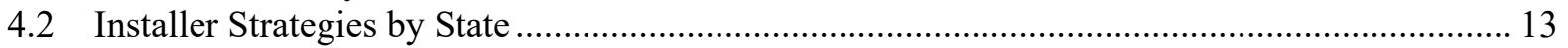

4.2.1 Arizona ................................................................................................. 13

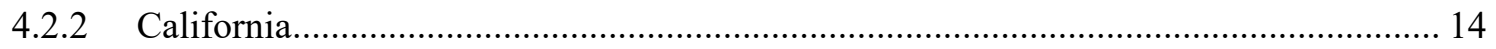

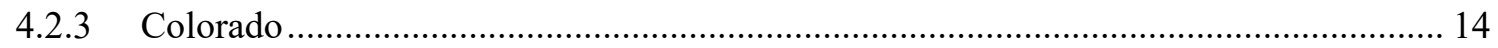

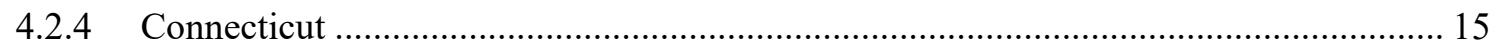

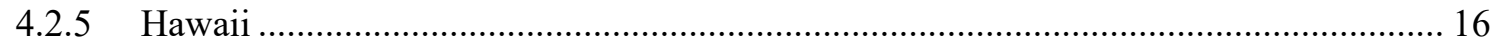

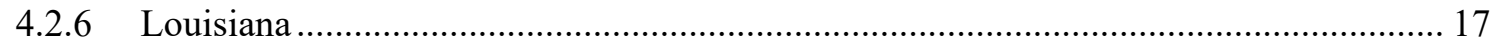

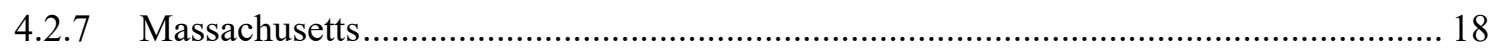

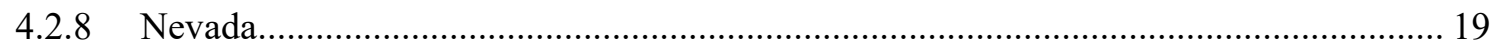

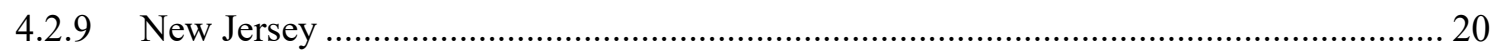

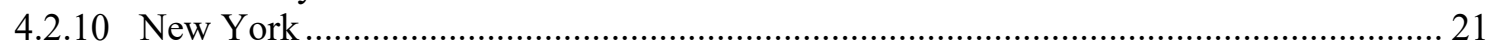

4.2.11 Summary of Findings from State-Level Analyses .............................................. 22

4.3 Installer Strategy: Reactions of Incumbent Installers or the Result of Installer Turnover? ........ 22

5 Discussion...................................................................................................................... 26

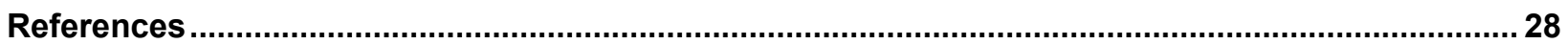




\section{List of Figures}

Figure 1. PV customer choice framework

Figure 2. Market shares of TPO versus customer-owned systems (based on data from Barbose and

Darghouth 2017).

Figure 3. Relationships among the financing platform (financier), installer partners, and customers......... 9

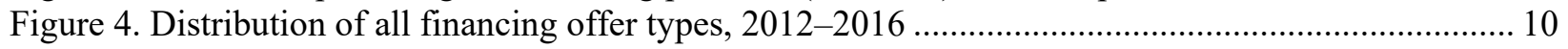

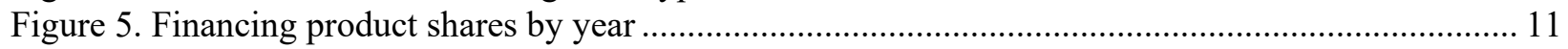

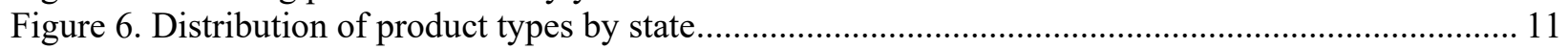

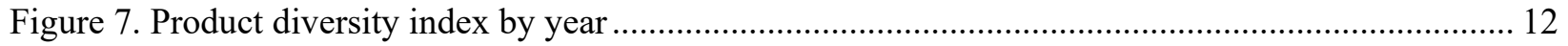

Figure 8. Product diversity index by state $(2012-2016)$.................................................................... 12

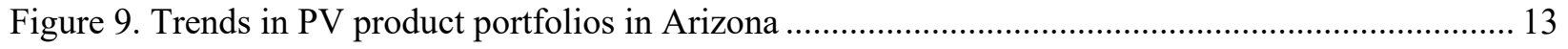

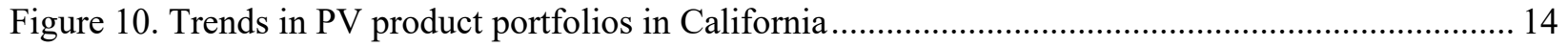

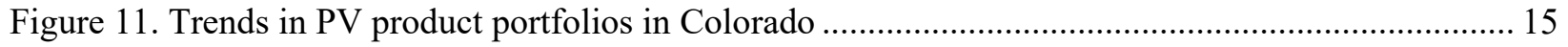

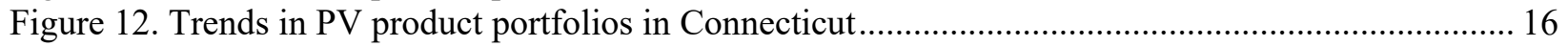

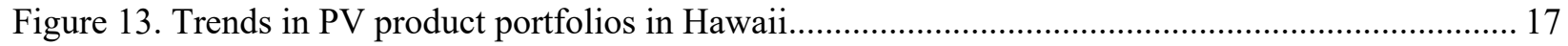

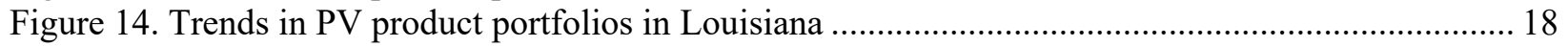

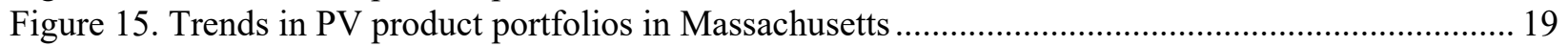

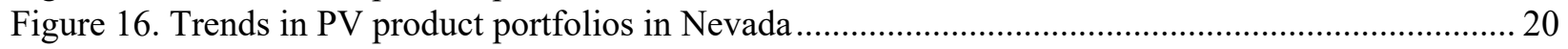

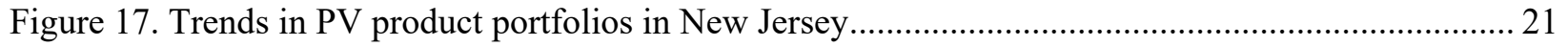

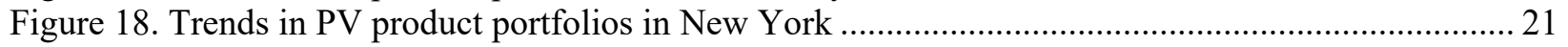

Figure 19. Distributions of product types over time for incumbents and transients .................................2 23

Figure 20. Product diversity over time for incumbents and transients.............................................. 23

Figure 21. Percentage of quotes using TPO by incumbent and transient installers in Arizona .................. 24

Figure 22. Percentage of quotes using prepaid TPO by incumbent and transient installers in Hawaii ...... 25

Figure 23. Percentage of quotes using TPO by incumbents and transients in New York ........................25

\section{List of Tables}

Table 1. Residential PV Product Options 1 


\section{Introduction}

In the past decade, the residential solar photovoltaic (PV) industry has developed various financing products that have expanded customer choice about how to procure PV (Table 1). In the late 2000s, PV suppliers developed third-party ownership (TPO) products-including power purchase agreements (PPAs), leases, and prepaid products - through which customers could use $\mathrm{PV}$ without incurring a large upfront cost or risks of ownership. More recently, several installers and lenders have begun offering solar loans to help customers finance system purchases.

Table 1. Residential PV Product Options

\begin{tabular}{lll}
\hline Product & System Ownership & Description \\
\hline $\begin{array}{l}\text { Cash purchase } \\
\text { PPA }\end{array}$ & $\begin{array}{l}\text { Customer } \\
\text { TPO }\end{array}$ & $\begin{array}{l}\text { Customer makes upfront payment to own system. } \\
\text { Customer makes ongoing volumetric }(\$ / \mathrm{kWh}) \\
\text { payments for system output. }\end{array}$ \\
Prepaid & TPO & $\begin{array}{l}\text { Customer makes monthly }(\$ / \text { month) payments to use } \\
\text { PV system. }\end{array}$ \\
Solar loan & TPO & $\begin{array}{l}\text { Customer makes upfront payment for a TPO system } \\
\text { to reduce or eliminate ongoing payments. } \\
\text { Customer receives financing to purchase and own } \\
\text { PV system. }\end{array}$ \\
\hline
\end{tabular}

PV customer choice has generally been studied from the customer's perspective. Research grounded in behavioral economics and diffusion of innovation theory shows that TPO options remove certain barriers to $\mathrm{PV}$ adoption, providing alternative and often attractive choices for customers. TPO reduces upfront costs, diminishes the risk and complexity associated with PV ownership, and frames financial benefits in easy-to-understand electricity bill savings (Drury et al. 2012). TPO financing attracts customers who have concerns about operation and maintenance and a lack of upfront funds (Rai and Sigrin 2013; Rai et al. 2016). Altogether, the ability of TPO to alleviate the risks and financial burden surrounding PV has encouraged new customer segments to adopt PV, contributing to the rise of TPO to $72 \%$ of the national residential PV market in 2014 (Litvak 2016).

However, regardless of the potential benefits of TPO, not all prospective customers have access to TPO products. Customer choice can be constrained by state and local policies that regulate TPO products (Kollins et al. 2010) and by the product portfolios or strategies of locally available installers. The market and infrastructure perspective on innovation diffusion suggests that supply-side factors enhance or constrain customer access to new technologies and services (Brown 1981). This diffusion of innovation framework is increasingly relevant in the residential $\mathrm{PV}$ industry, which is expanding at varying rates in markets with diverse policies, installer strategies, and customer characteristics. A key insight from this theory is that customer access to PV innovations (e.g., TPO financing products) varies as a function of decision making among PV suppliers. Further, this theory suggests that trends in the diffusion of innovations such as TPO financing should not be interpreted as solely a result of changing customer preferences; supply-side forces that limit customer choice may obscure instances in which customers prefer alternative financing products. 
Figure 1 illustrates a customer choice framework combining customer preferences and the market and infrastructure perspective. Under this framework, customer preferences influence the types of products that prospective adopters may pursue, but customer choice may be constrained by local TPO policies and/or the products offered and marketed by locally active installers. Enhanced customer choice allows customers to adopt PV through the financing product that best meets their needs. Notably, however, anecdotal evidence from installers suggests that there is a tradeoff between customer choice and confidence and that too many purchase options can create customer confusion and reduce sales rates.

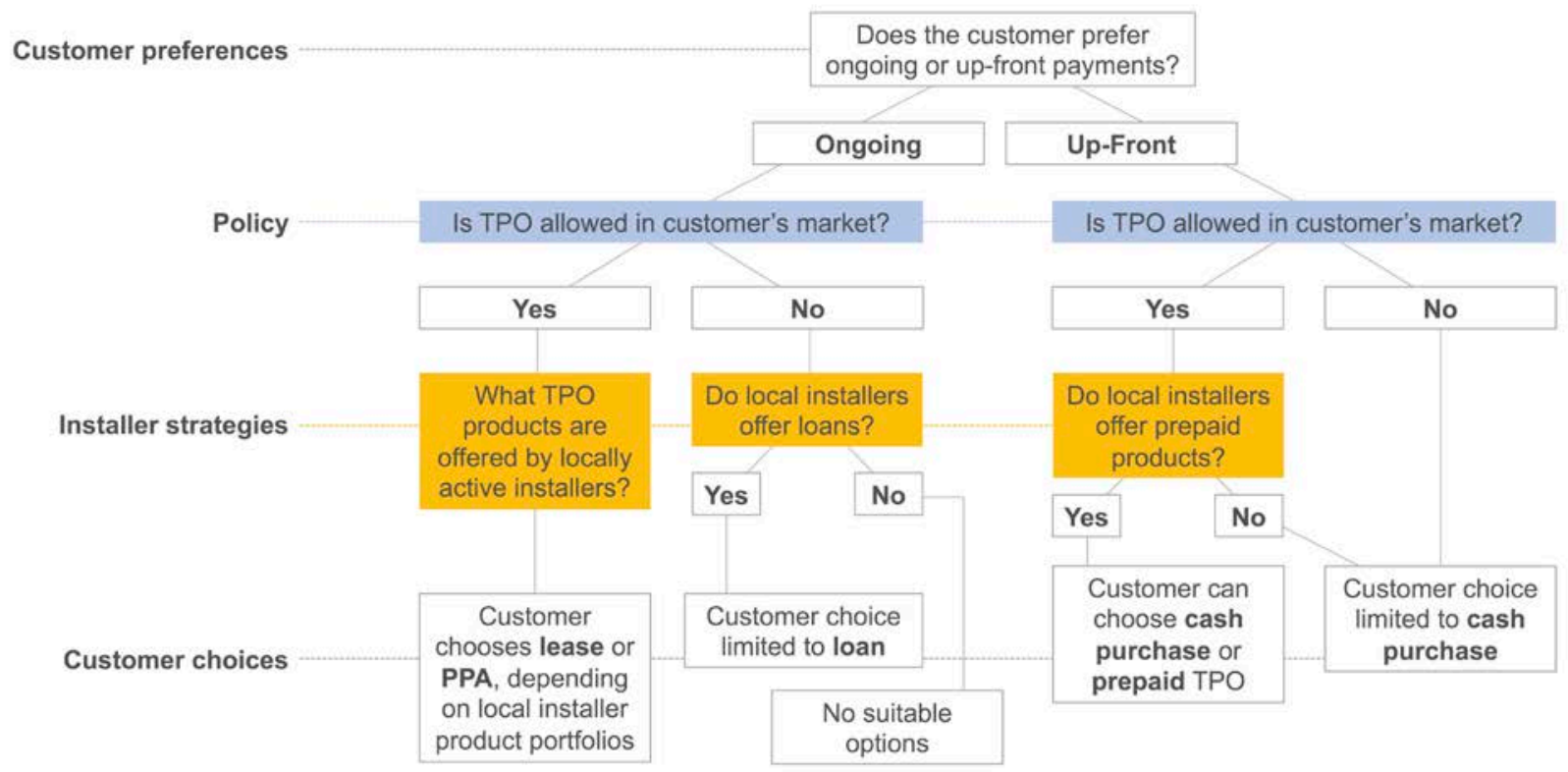

Figure 1. PV customer choice framework

The policy level of this framework is increasingly facilitating enhanced customer choice as states pass TPO-enabling reforms, but installer strategies remain a key supply-side barrier to customer choice. Because TPO products are primarily offered by high-volume, national-scale installers (MIT 2015; O’Shaughnessy 2018), TPO markets are highly sensitive to the strategies of these installers. For instance, a recent shift from TPO to loan and cash sales among a few leading national-scale installers has contributed to declining TPO sales (Mond 2018). In a market comprising about 2,000 companies, changing strategies among only a few companies have driven noticeable changes in PV product trends and customer choice.

In contrast to national-scale installers, small and mid-scale installers generally cannot offer PV financing on their own. ${ }^{1}$ One way to reduce market sensitivity to national-scale installer strategies is to connect smaller-scale installers to financiers via an intermediary financial services entity. For instance, some software platforms allow installers to manage customer information and generate installation and financing quotes for PV systems. These services are available to all

\footnotetext{
${ }^{1}$ The term "long-tail" has been used to describe the large number of small and mid-scale installers in the PV installation industry, though the term has no fixed numerically based definition.
} 
installers, but these platforms have primarily been used by small to mid-scale installers that have not historically had access to PV financing.

In this study, we analyze how and why small and mid-scale installers who used a financing platform adjusted their product offerings over time and by state. Our results enable us to explore the influence of these smaller installers - and the influence of financing platforms available to such installers - on customer access to diverse PV financing products in the context of changing policy and market conditions. We analyze 599,496 PV installation quotes made in 10 states between 2012 and 2016 by 1,706 installers on a financing platform, henceforward referred to as "the platform." The data set is unique in three respects. First, whereas many publicly available PV databases include installation-level observations that reflect the PV systems selected by customers, observations in this study's data set are at the quote level. This enables analysis of the quotes offered by installers - that is, installer strategies - rather than customer uptake. Second, whereas many data sets specify whether a PV system is customer owned or TPO, this study's data set provides insights into the specific financing product associated with each quote: cash, PPA, lease, prepaid, or loan. This detail enables investigation of financing trends at a more granular level. Finally, this study's data set primarily represents quote activity among small to mid-scale installers, ${ }^{2}$ which are generally overlooked in PV market analyses that focus on trends among the leading six to ten installers. Given projections for double-digit growth among small to mid-scale installers (Mond 2018), analysis of these installers' strategic behavior may yield insights into future trends in PV customer choice overall, not only as dictated by the industry's largest firms.

The remainder of this report is organized as follows. Section 2 provides background about demand- and supply-side factors that explain recent trends in the national TPO market and constrain customer access to financing options. This discussion introduces the challenges that smaller-scale installers have historically faced in providing TPO financing services, highlighting the role of intermediaries in expanding installer and customer access to TPO. Section 3 summarizes the financing platform business model and the data set of quotes used in our analyses. Section 4 presents our analysis of installer strategies on the platform. Section 5 discusses the key findings and implications of our analysis.

${ }^{2}$ The top five TPO installers, which account for about 89\% of TPO sales (Mond 2018), account for less than $0.1 \%$ of the quotes in the data set. 


\section{Background}

Research on the diffusion of PV has primarily assumed an adopter perspective and investigated how customer motivations, information preferences, risk characteristics, and financial position affect decisions to adopt residential PV (Rai and Sigrin 2013; Rai et al. 2016; Reeves et al. 2017). This research indicates that the risk-reduction and upfront cost-reduction characteristics of TPO appeal to certain customer segments and have facilitated a broadening of the residential PV market.

However, adopter-focused diffusion of innovation theory may have limited ability to explain the decline and divergence of TPO share across various state markets. Because of strategic decisions, lack of access to financing, or unfavorable public policies, installers do not always include TPO products in their portfolios. As the residential PV industry has evolved into broader geographies, variable installer strategies and public policies have left some customers with limited financing options.

This section begins with a brief introduction to PV customer options in residential PV financing, followed by a summary of TPO trends from 2010 to 2017. We outline a variety of demand- and supply-side factors that likely contributed to the national-scale rise and fall of TPO markets as well as the divergence of TPO trends across states. We close with a discussion of small and midscale installers' projected role in evolving PV markets and the ongoing importance of financing platforms.

\subsection{Customer Choice: PV Financing Products}

Three general forms of financing options are available in the residential PV market: cash purchase, loans, and TPO (Speer 2012). Customers who purchase with cash or a loan retain ownership of PV systems, while third-party providers own PV systems in TPO transactions.

Cash purchases usually result in the lowest net costs to residential PV customers (Speer 2012; Davidson et al. 2015; MIT 2015), but the high upfront investment is a barrier to many customers. Loan options can help customers overcome this investment barrier while giving them ownership, although interest payments increase system costs over the life of the loan. Lenders typically require homeowners to meet credit and debt-to-income qualifications, limiting this option for some customers.

TPO financing is available in the form of leases, PPAs, and prepaid contracts. In a TPO transaction, customers enter into a long-term contract with a third-party provider to lease system hardware or procure PV output. TPO contract lengths vary, with a standard length of about 20 years (MIT 2015), and many TPO options include a buyout plan. Like solar loans, TPO financing typically requires customers to meet credit and debt-to-income qualifications. From a customer perspective, the key difference between a lease and a PPA is the payment structure. In a lease, customers make fixed monthly payments, whereas PPA customers make volumetric $(\$ / \mathrm{kWh})$ payments. Both leases and PPAs may include escalator clauses that result in increasing payment rates over time. Finally, under a prepaid contract, customers make large upfront payments to reduce or eliminate ongoing payments to the third-party provider. 
Typically, customers pay lower net costs when purchasing via cash or loan rather than signing a TPO contract. Most federal, state, and local incentives accrue to system owners rather than to lessees or offtakers (PPAs). The federal investment tax credit (ITC) has subsidized solar investments since 2005, allowing residential and commercial PV owners to claim a federal tax credit of $30 \%$ of the eligible cost basis of the system. Modified accelerated cost recovery system (MACRS) depreciation allows commercial PV owners to deduct $85 \%$ of system costs from taxable income on an accelerated five-year depreciation schedule. Residential PV customers with significant tax liability can take advantage of the ITC and other locally available tax incentives when they purchase systems using cash or a loan, although they are not eligible for MACRS. In a TPO transaction, a PV installer "sells" the system to a third-party investor who monetizes MACRS, the ITC, and any other available incentives while retaining a fee. The remaining value of the tax incentives accrues back to the installer through a variety of arrangements such as partnership flip, sale-leaseback, or inverted lease (MIT 2015), and installers can then pass these benefits through to customers in leases or PPA contract terms. One of the primary liabilities of PV ownership is that system owners are typically responsible for ongoing costs such as operation and maintenance (O\&M). PV systems require cleaning, monitoring, repair, and inverter replacements to ensure maximum efficiency and productivity. Homeowners who do not have the technical know-how to operate and maintain their PV system may have to hire a contractor to manage O\&M, which increases system costs. TPO providers often, though not always, include O\&M services in their contracts with customers to counteract concerns about the risks of ownership.

One additional factor that affects the economics of PV is that installers incur costs when switching to new or more diverse financing product portfolios. Initiating and closing funds to back TPO products requires installers to pay legal fees and make labor commitments. Once funds are secured, installers may need to train sales teams about how to effectively pitch new financing products. As a result, customers may pay a premium in markets in which installers compete to offer diverse financing options.

\subsection{TPO Trends}

After TPO financing first became widely available in 2008, it rapidly gained share in the most mature state markets. By the end of 2012, annual TPO market share exceeded $90 \%$ in Arizona, $80 \%$ in Colorado and New Jersey, 70\% in California, and 60\% in Massachusetts (Kann 2013). Nationally, TPO reached a peak market share of $72 \%$ in 2014 (Litvak 2016). ${ }^{3}$

In 2015, however, the national-level share of TPO dropped to 62\% (Figure 2), largely driven by a decline below $60 \%$ in the largest PV market, California (Litvak 2016). Meanwhile, other states maintained strong TPO markets, including New Jersey ( $>90 \%$ TPO in 2015), Arizona ( $>80 \%)$, Colorado ( $>70 \%)$, and New York (>70\%) (Litvak 2016). This divergence of TPO trends among states has continued. California has experienced ongoing drops in TPO, reaching 33\% in the second half of 2017 (Mond 2017). States including Arizona (63\% in the second half of 2017), Massachusetts (62\%), New Jersey (80\%), New York (64\%), and Colorado (73\%) have maintained strong but volatile TPO markets (Mond 2017).

\footnotetext{
${ }^{3}$ Estimates of TPO penetration vary based on data sources. Estimated TPO penetration in Litvak (2016) is generally higher than TPO estimates based on data from Barbose and Darghouth (2017), illustrated in Figure 2.
} 


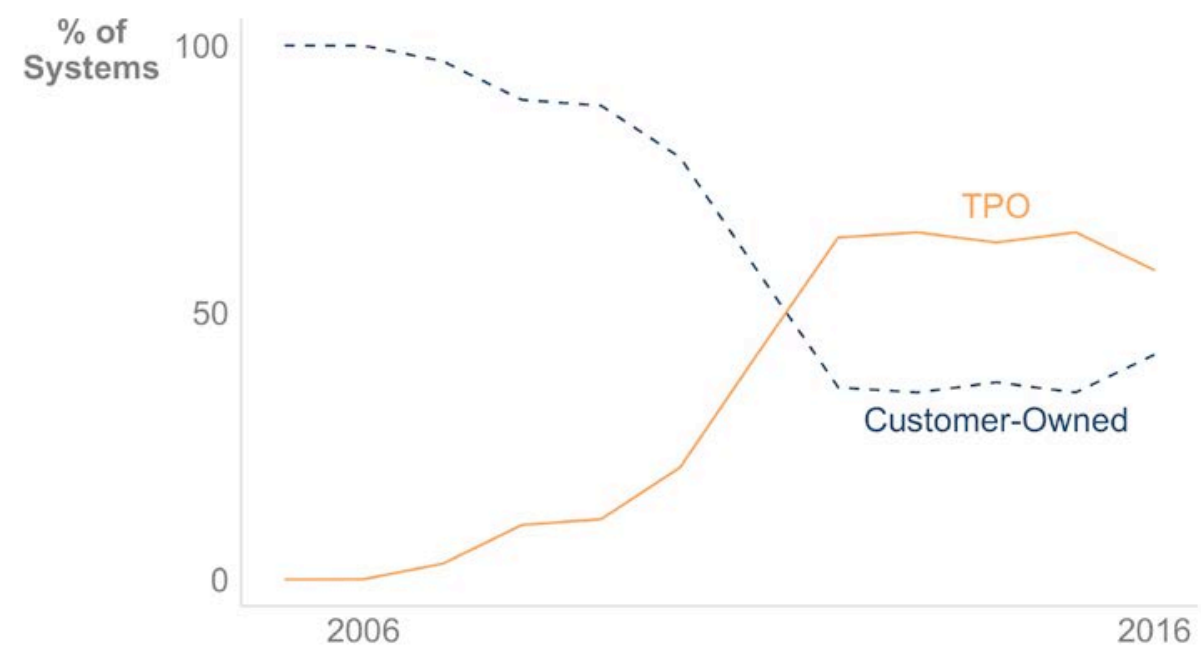

Figure 2. Market shares of TPO versus customer-owned systems (based on data from Barbose and Darghouth 2017)

\subsubsection{Demand-Side Drivers}

The dominant explanation for the rise of TPO is that it enabled customers to reduce the risks and upfront costs of PV adoption (MIT 2015; Kann 2013; Drury et al. 2012; Rai et al. 2016).

Analogous to leasing options in the automobile market, TPO allows customers to offload risks of ownership to a third-party provider (Dasgupta et al. 2007; Drury et al. 2012). Additionally, leases and PPAs enable customers to pay for access to PV over time rather than in large upfront sums.

By allowing customers to choose new financing products that better aligned with their risk preferences and financial needs, TPO made PV accessible to broader consumer segments (Rai et al. 2016). In southern California, TPO attracted younger and less affluent customers (Drury et al. 2012). In the early Texas market, leases were particularly successful among customers with less available cash and more uncertainty about PV technological performance (Rai and Sigrin 2013). Key determinants of northern California customers' decisions to adopt via TPO included concerns about O\&M and availability of upfront funds (Rai et al. 2016). Altogether, TPO appears to be successful with customers who are "information-ready" to consider PV but need additional risk or capital-investment reduction to adopt (Rai and Sigrin 2013; Rai et al. 2016).

Diminishing customer demand for TPO in part explains the decline of the national-scale TPO market since 2015. Falling prices have made PV more affordable and reduced the financial risks of ownership (Litvak 2016). The anticipated phaseout of the ITC in 2016 increased urgency for homeowners with tax liability to purchase directly, leading to an increase in system ownership relative to TPO (Litvak 2016). Additionally, increasing availability of competitive loan terms provided a pathway for customers to finance PV while also receiving ownership incentives.

\subsubsection{Supply-Side Drivers}

Demand-side factors alone cannot explain the heterogeneous penetration of TPO across state and local markets. The market and infrastructure perspective on innovation diffusion emphasizes that supply-side factors such as timing of market formation, supplier strategies, and public policy affect customer access to innovations (Brown 1981). In the context of U.S. residential PV, three 
key supply-side factors drive customer choice: policy, barriers to financing for installers, and TPO market concentration.

\subsubsection{Policy}

In the early 2000 s, the development of TPO products was stymied by regulations that prohibited non-utility entities from selling retail electricity (Kollins et al. 2010). Over time, states have amended or clarified utility regulations in ways that exempt TPO providers from such prohibitions and allow for TPO sales. By 2018, TPO sales had been authorized in 26 states and Washington, DC, while nine states and some municipal jurisdictions had legal barriers to TPO (DSIRE 2018). Some jurisdictions - such as Arizona, Florida, and the Los Angeles Department of Water and Power (LADWP) — allow leases while prohibiting PPAs.

Other state and local policies may influence installer strategies without directly enabling or prohibiting specific PV products. Net-metering policies that compensate PV system owners for PV output delivered to the grid can change system economics in ways that may affect installer strategies (e.g., Nevada, see Section 4.2.8). Some states have implemented incentive structures that vary according to system ownership in ways that may favor one form of ownership and may influence installer strategies (e.g., Colorado, Section 4.2.3). Policy uncertainty can influence installer strategy by reducing investor confidence in PV markets (e.g., Hawaii, Section 4.2.5).

\subsubsection{Barriers to Financing for Installers}

Small and mid-scale installers have largely been excluded from TPO markets, which have been dominated by high-volume installers able to tap the tax-equity capital needed to offer attractive TPO products. In a typical TPO transaction, an installer sells portfolios of PV systems to a taxequity investor. The tax-equity investor monetizes available tax incentives, retains a fee for services, and then passes savings back to the installer and ultimately to the customer. Tax equity is a crucial instrument to ensure the complete monetization of tax incentives, given that most installers and customers have insufficient tax liabilities to monetize these incentives fully on their own. Tax-equity investors typically require asset portfolios valued in the tens to hundreds of millions of dollars (MIT 2015). As a result, only national-scale installers with sales volumes of thousands of systems per year have sufficient asset bases to attract low-cost tax equity.

Due in part to the tax-equity barrier, only about one in five installers installed a TPO system in 2016 (O’Shaughnessy 2018). Customers who choose to interact primarily with small local installers may therefore have fewer PV financing choices, unless local installers can access financing through an intermediary such as a financing platform.

Even if financing platforms are available, platform policies may still limit installer strategies. Customer choice is therefore at least partially determined by the strategies of installers and financing platforms, and financing trends should not be interpreted solely as reflections of changing customer preferences.

\subsubsection{TPO Market Concentration}

In part due to the reliance of TPO on tax equity, the leading six PV providers have held $90 \%$ to 99\% of the TPO market since 2012 (Litvak 2015, Mond 2018). Lawrence Berkeley National Laboratory's Tracking the Sun database indicates similar market concentration in 2016, when 
firms installing more than 1,000 systems per year accounted for about $82 \%$ of the TPO market (O’Shaughnessy 2018).

As a result of market concentration, TPO trends are highly sensitive to changes in the strategies of leading firms. For example, the rise in TPO was heavily influenced by the strategies of Tesla/SolarCity and Vivint Solar. When TPO peaked in 2014, the sales portfolios of these two firms were $100 \%$ and $94 \%$ TPO, respectively, together making up $47 \%$ of the total residential PV market. These firms are now widely believed to be driving the national-scale drop in TPO market share (Mond 2017). After SolarCity and Vivint Solar went public in 2012 and 2014, respectively, public markets increasingly have demanded that these firms improve their profitability and cash positions (Litvak 2016). In response, these firms are offering more loans and fewer TPO options to their customers (Mond 2017). Thus, strategic shifts in just a few companies can reshape customer choice in the U.S. residential PV market.

\subsection{Implications}

While shifting customer preferences have in part driven variation in TPO trends across the country, supply-side factors have great impact on PV customer choice. Regions in which leading TPO providers are not active are unlikely to have access to TPO products. Increasingly, even regions served by leading installers may have decreasing access to TPO products as some of these firms make strategic shifts from TPO products to loans. The combined effects of demandand supply-side factors on PV customer choice are summarized in the customer choice framework in Figure 1.

Moving forward, small to mid-scale PV installers may play a role in expanding TPO options in emerging markets to meet ongoing demand for risk and upfront-cost reduction. These installers are often the "first movers" in new markets (Mond 2018). Because these installers act as the first information channel for new potential customers, their financing product portfolios and strategic choices may motivate customer decision making about how to adopt (Rai et al. 2016).

Financing firms enable smaller-scale installers to access TPO and other financing products. Though the share of the TPO market that is conducted via financing platforms is published in some reports (Kann 2013; Litvak 2014; Litvak 2015; Mond 2017), detail about installer use of these platforms has not yet been made publicly available. Subsequent investigation of platform quoting activity contributes to solar market research by unpacking the strategies of small to midscale installers when provided the opportunity to sell a variety of PV financing products. 


\section{Data}

The data set used in this analysis includes 599,496 quotes made by 1,706 installation companies to PV customers in 10 states between 2012 and 2016. ${ }^{4}$ Each quote is associated with a PPA, lease, prepaid, cash, or loan financing product. ${ }^{5}$ The relationships among the financing platform, its installer partners, and residential PV customers are described in Figure 3. Typically, the first contact occurs between the installer and the customer. When a customer requests financing that an installer cannot provide, or when an installer seeks to offer financing services as a way to increase customer acquisition, the installer approaches the platform. Installers complete an application process that certifies them to sell specific financing products. The platform sells the installer access to its platform, on which installers design quote specifications such as price, system components, and financing products. The installer sends these quotes to the platform, which then provides the quotes to the customer.

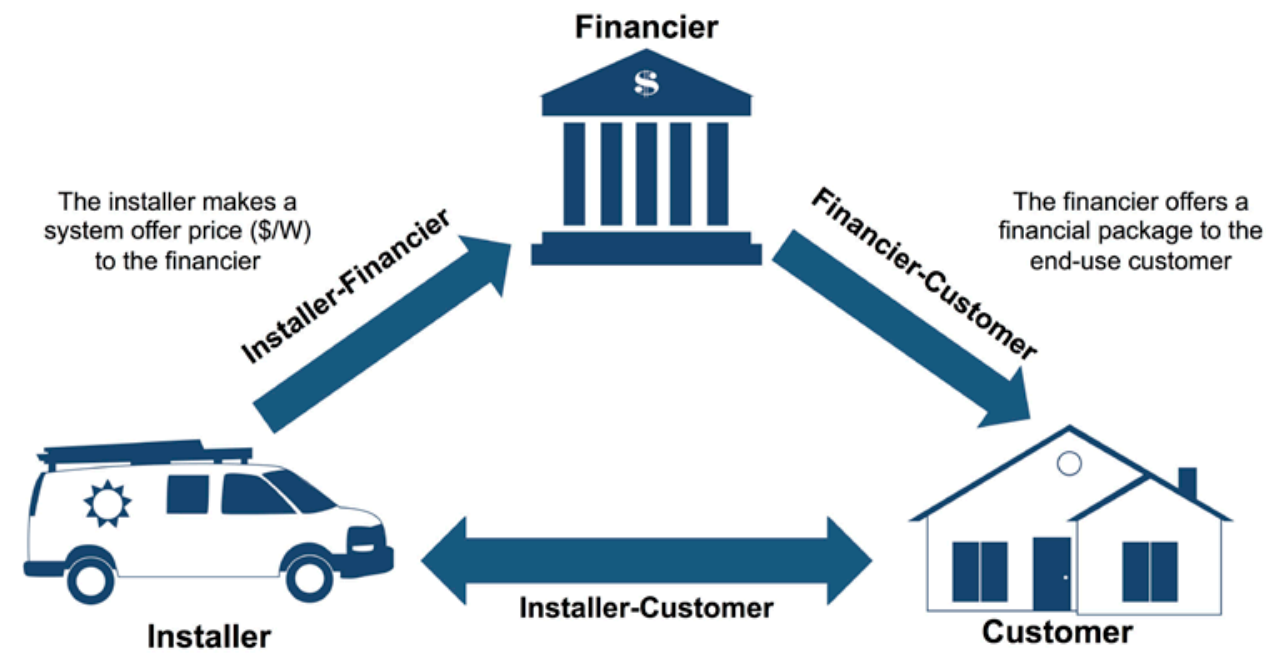

Figure 3. Relationships among the financing platform (financier), installer partners, and customers

The platform determines which financing products are available to quote based on whether an installer is cleared to sell them and whether the products are available in the customer's state. For example, customers in states that expressly regulate parties engaged in PV PPAs as utilities would not be eligible for PPA quotes on the platform. If installer qualification and geographic eligibility criteria are met, installers choose which financing products and how many quotes to present to each customer. We use installer product choices as evidence of installer strategies.

\footnotetext{
${ }^{4}$ The data represent a subset of the full data set for states with at least 1,000 quotes.

${ }^{5}$ TPO providers design variations in financing products - such as length of roof warranty, product change fees, cost to move the system, and maximum degradation fees - that can be used to compete against other providers.
} 


\section{Analysis}

We explore trends in installer strategies in terms of the timing, geography, and diversity of financing product quotes on the platform, using shifts in product offerings and product diversity as evidence of changes in installer strategies that affect customer choice. Section 4.1 explores basic trends in product diversity. Section 4.2 examines state-level trends in installer strategies over time. Section 4.3 analyzes the contributions to observed installer strategy changes of shifting incumbent installer strategies versus installer turnover.

\subsection{Product Diversity}

About $42 \%$ of quotes on the platform represented cash offers (Figure 4). Installers may have posted cash offers for one of two reasons. About $8 \%$ of customers who received a cash quote also received a quote for some other product. In these cases, installers may have provided a cash offer as an alternative to a TPO product. The remaining $93 \%$ of customers who received a cash quote did not receive any other offer. In these cases, the installer may simply have used the platform as a way to organize customer information and develop customer relationships.

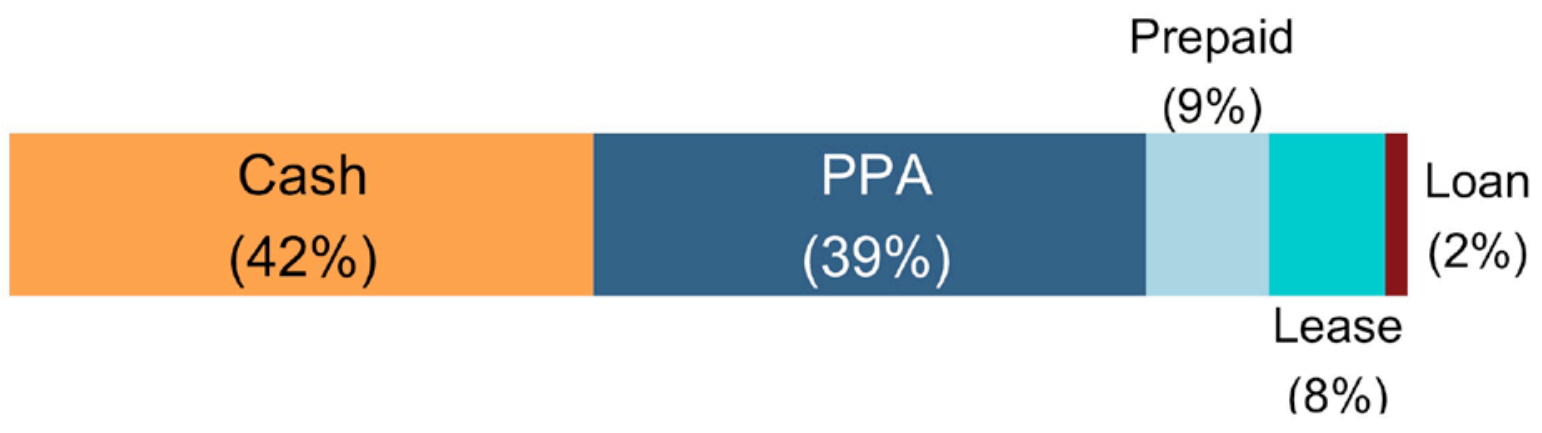

Figure 4. Distribution of all financing offer types, 2012-2016

Cash offers were the most common product offered on the platform from 2012 to 2015 (Figure 5). PPAs became more popular over time, increasing from about $23 \%$ of quotes in 2012 to $56 \%$ in 2016, when they surpassed cash as the most common product on the platform. This TPO increase occurred even as TPO products lost share in the broader PV market beginning around 2015, perhaps reflecting the increasing comfort of the platform's installers with PPAs. The platform shares of the other financing products generally declined over time. 


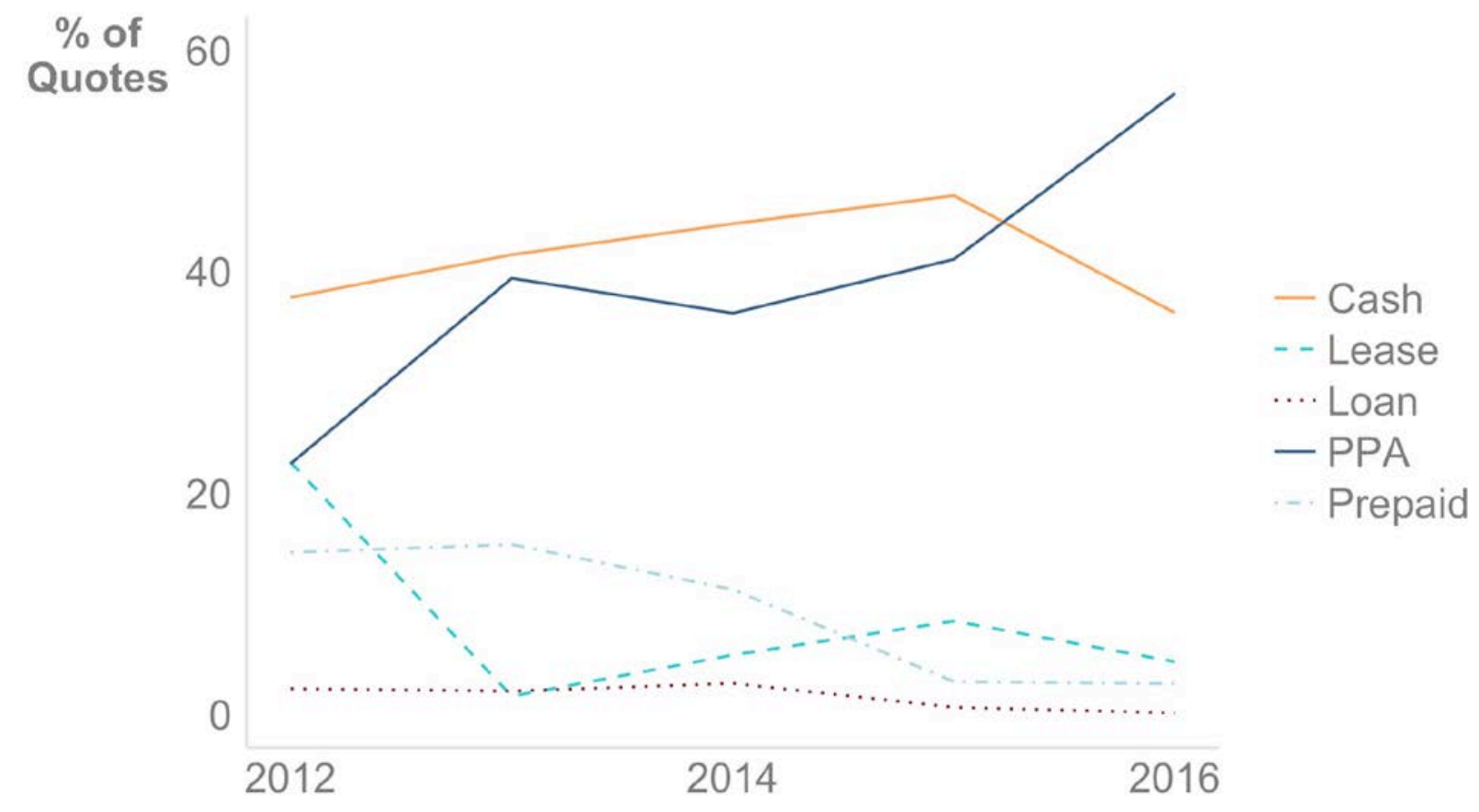

Figure 5. Financing product shares by year

Prevalence of the different products varied across states (Figure 6). Installers offered all five products in only three states: California, Colorado, and New York. In the remaining states, at least one financing product was completely absent, typically leases. Cash was the most common product offering in five of the ten states, including California. Leases were the most common product type in Arizona, and PPAs were the most common product type in Colorado, Connecticut, New Jersey, and New York.

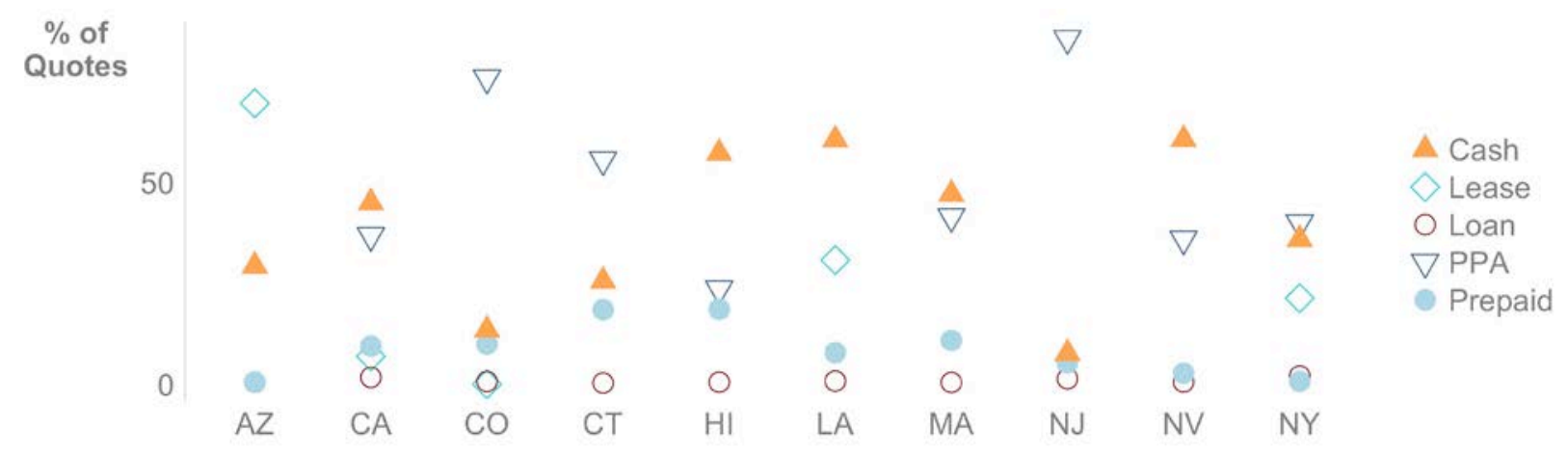

Figure 6. Distribution of product types by state

To quantify product diversity, we use a variant of a concentration index, which we refer to as a product diversity index:

$$
\text { product diversity index }=1-\sum_{P=1}^{5} s_{P}^{2}
$$


Where $s_{P}^{2}$ is the squared share of product $P$ among all quotes in some given market. The product diversity index ranges from 0 to 0.8 , with 0 representing a market in which only a single product is offered, and 0.8 representing a market in which all five products are offered evenly (i.e., each product constitutes $20 \%$ of the quotes). Product diversity declined over time on the platform, suggesting that customers generally chose from fewer products in 2016 than in 2012 (Figure 7). Declining product diversity was primarily driven by the declining prevalence of leases and prepaid products on the platform during this period.

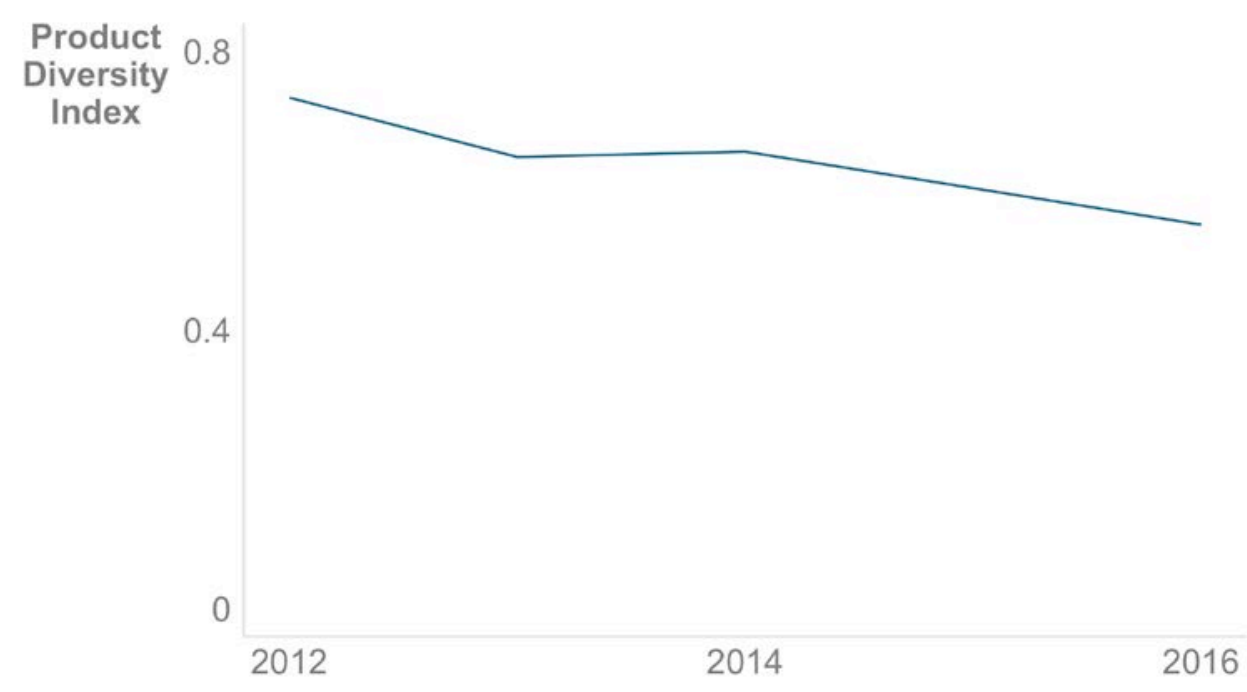

Figure 7. Product diversity index by year

Product diversity varied considerably across states when analyzed cumulatively over the entire study period (Figure 8). California and New York - two of the most mature state-level PV markets - exhibited relatively high product diversity, suggesting that customers interacting with the platform's installers in these states generally chose from more PV products. In contrast, product diversity was relatively low in Arizona, Colorado, and New Jersey. As we discuss in Section 4.2, product diversity in these states might be attributable in part to policy factors. In Arizona, state-level regulations prohibit PPAs. In Colorado, utility incentives favor customer ownership. The dominance of PPAs in New Jersey has been attributed to the state's relatively volatile incentive program, which might decrease customer interest in direct ownership (Litvak 2015).

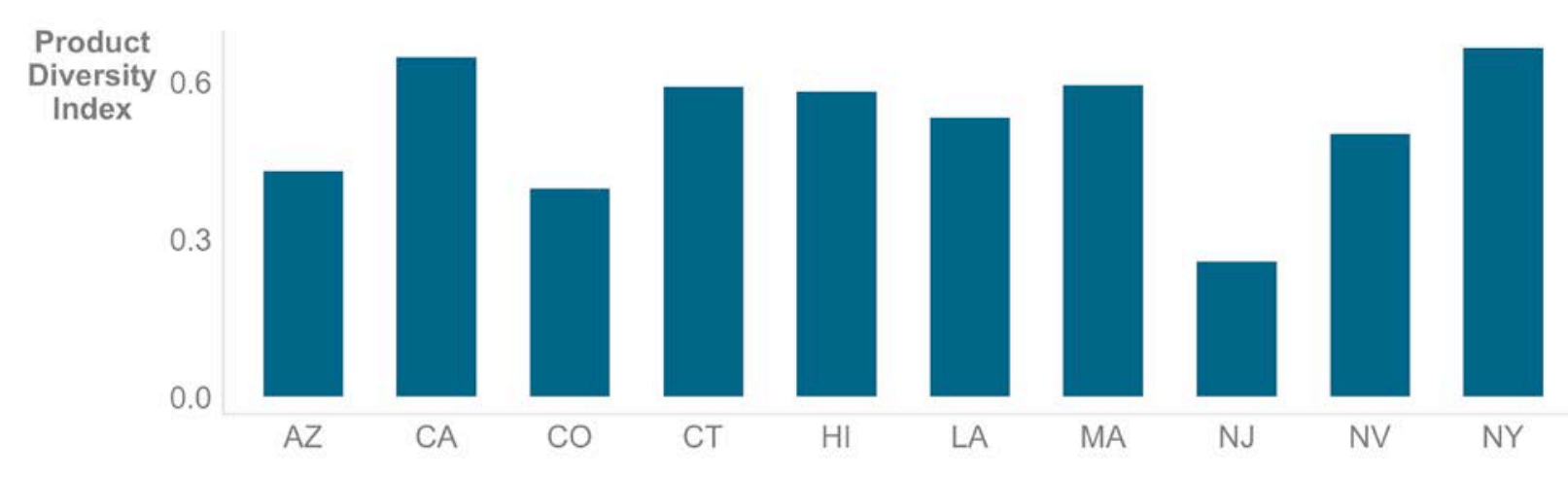

Figure 8. Product diversity index by state (2012-2016) 


\subsection{Installer Strategies by State}

Some of the product diversity trends described in Section 4.1 correlate with major policy reforms or changing market conditions. This section outlines potential policy and market factors that may have contributed to installer strategies in states with substantial platform installer activity.

\subsubsection{Arizona}

The platform's installers in Arizona generally offered a mix of cash and lease products, increasingly shifting toward leases from 2014 to 2016 (Figure 9). This shift corresponded to rate reforms by the state's two major IOUs, Arizona Public Service and Salt River Project. Both IOUs moved PV customers to fixed or demand charges in 2015, reducing volumetric rates and the potential for bill savings through PV adoption. As a result of these reforms, Arizona PV customers faced the worst economics of all major state markets (Litvak 2015). Arizona was the only major state market in which PV loan customers could not achieve savings in the first year of the loan term (Litvak 2015). Leased PV systems are exempt from property tax assessments in the state, enabling third-party providers to pass on some savings to customers and possibly explaining the prevalence of leases on the platform. Despite uncertainty about whether the Department of Revenue would begin to assess property taxes on leased PV systems in 2015, installers shifted from cash to lease offers from 2014 to 2016, resulting in declining product diversity (Figure 9, right pane).

The complete absence of PPAs is the result of state policy. In 2010, the Arizona Corporation Commission ruled that, though third-party PPAs signed by residential and private entities are subject to utility regulation, leases are not. ${ }^{6}$

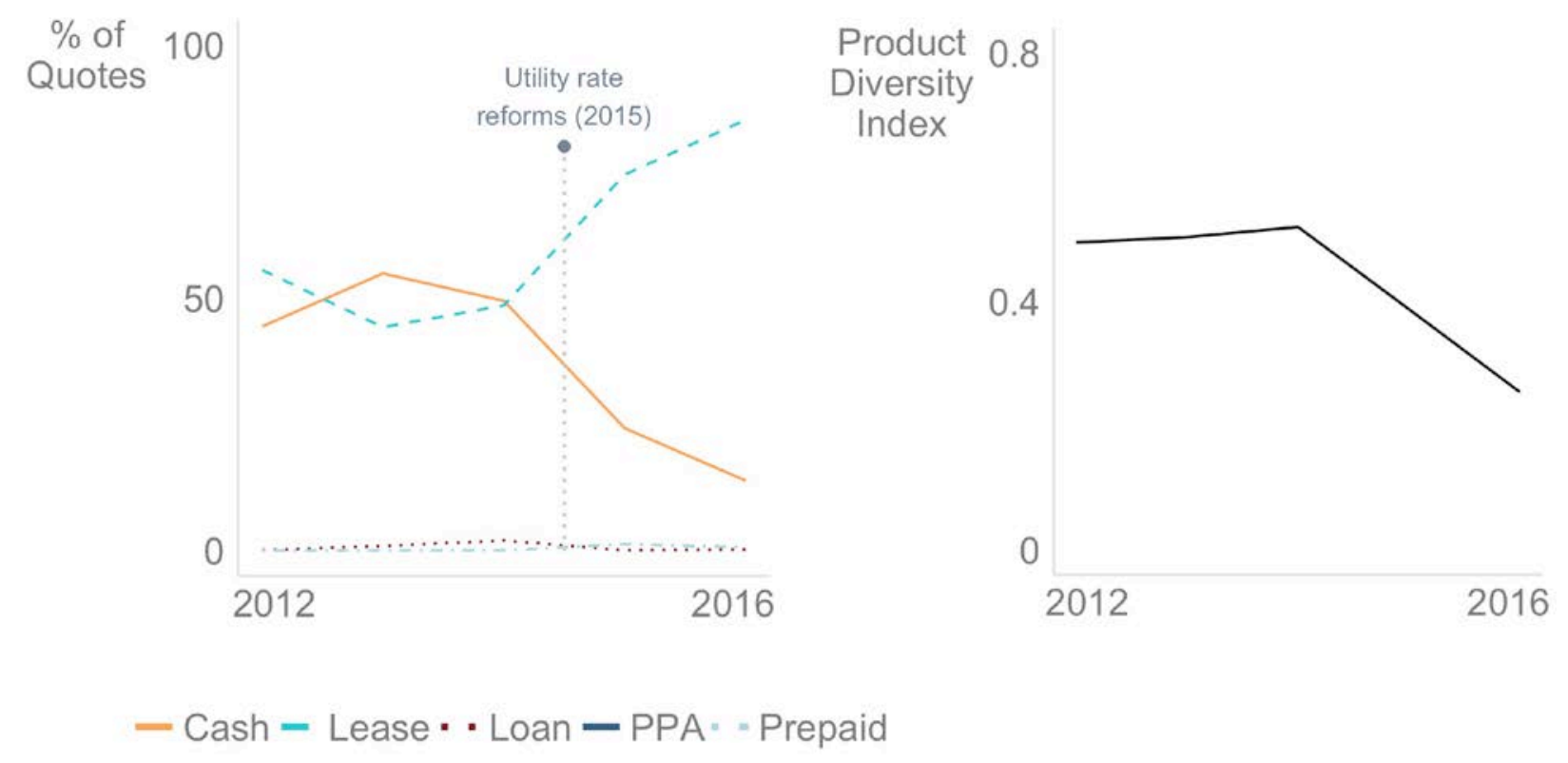

Figure 9. Trends in PV product portfolios in Arizona

\footnotetext{
${ }^{6}$ Decision 71795, Docket E-20690A-09-0346. PPAs signed by schools, governments, and other non-profit organizations are exempt.
} 


\subsubsection{California}

The platform's installers in California moved toward cash and PPA offers over time. ${ }^{7}$ By 2016, cash and PPAs each accounted for about half of California-based quotes (Figure 10). The move toward cash offers is consistent with broader market trends. TPO's share of the California market fell from over $70 \%$ in 2013 to $30 \%$ by 2017 (Kann 2013; Mond 2018). This trend was partially driven by the pivot of national-scale installers away from TPO and toward loans (Mond 2018). At the same time, the platform's installers gradually moved toward rather than away from PPAs and did not exhibit any shift toward loans. Product diversity gradually declined over time as installers coalesced around cash and PPA offers and moved away from leases and prepaid products (Figure 10, right pane).

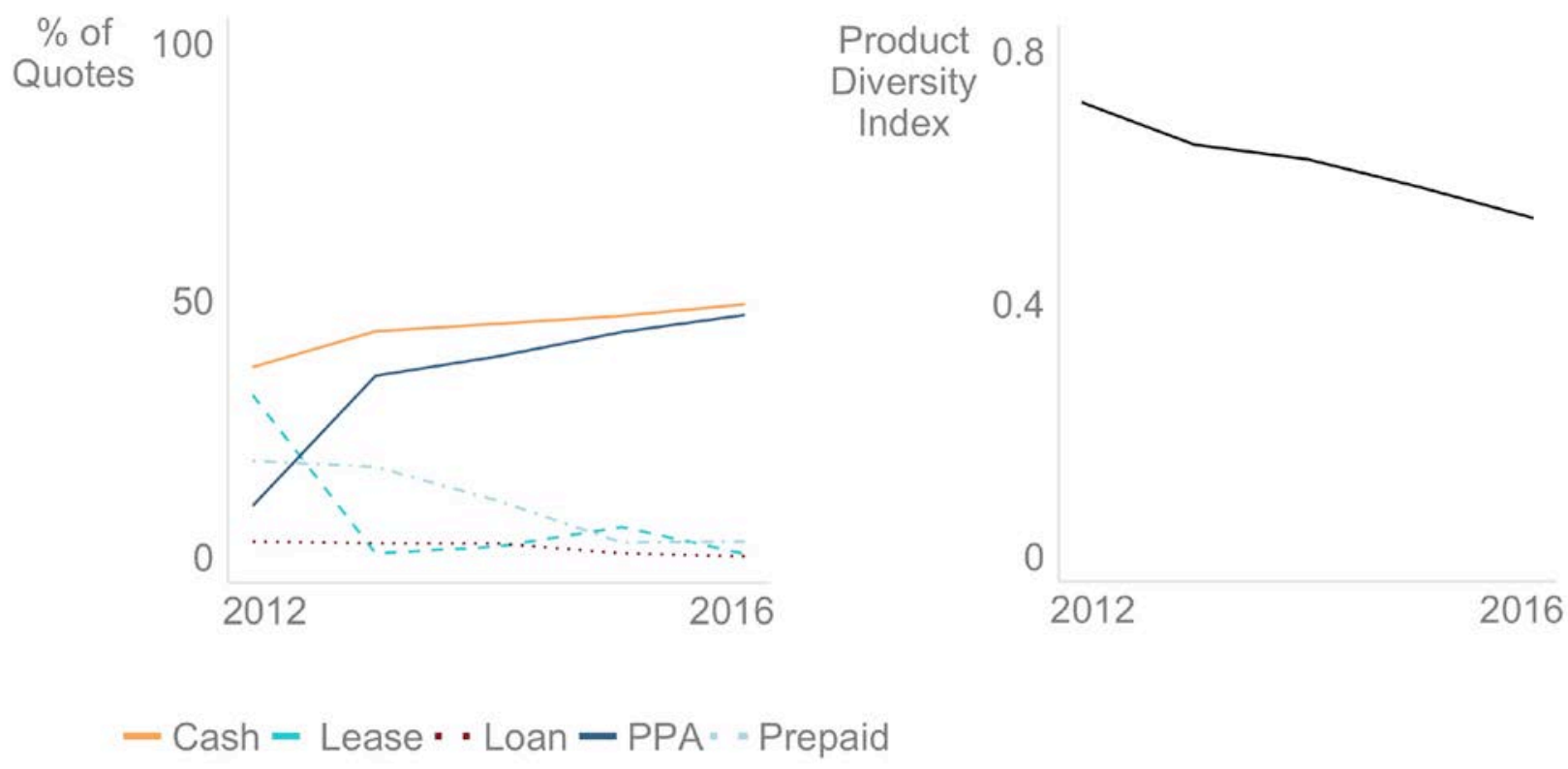

Figure 10. Trends in PV product portfolios in California

Declining product diversity in California is particularly important given that the state is, by far, the largest PV market in the United States. This trend suggests that customers of the platform's installers had fewer PV product options in 2016 than in 2012 in California. From a policy perspective, this outcome may not be desirable. Diverse product portfolios may allow diverse customers to choose options that work best for their individual circumstances, and declining product diversity may ultimately preclude some customers from adopting PV. Alternatively, the coalescence around PPAs and cash may simply reflect a consensus around the most desirable PV products in California. It is possible that PPAs are superior to other TPO options for most California customers owing to the state's unique policy and rate structure environment.

\subsubsection{Colorado}

The platform's installers in Colorado primarily offered PPAs from 2012 to 2014 before rapidly switching to cash, loans, and prepaid in 2015 and 2016 (Figure 11), consistent with broader market trends (Litvak 2015). The shift toward cash and loans was driven, in part, by changes to

${ }^{7}$ LADWP prohibits the sale of solar PPAs in its service territory, contributing to a lower overall prevalence of PPAs. This policy was in place over the entirety of the study period and does not affect temporal trends. 
the state's PV incentive structure. Before 2014, the state's IOU, Xcel Energy, offered a production-based incentive equal to $\$ 0.02 / \mathrm{kWh}$ for customer-owned systems and below $\$ 0.01 / \mathrm{kWh}$ for TPO systems. In 2014, Xcel modified the structure so that customer-owned systems received $\$ 0.03 / \mathrm{kWh}$ while TPO systems received $\$ 0.01 / \mathrm{kWh}$. The incentive structure results in roughly $\$ 200 /$ year of additional savings for customer-owned systems relative to TPO systems, depending on system size. National-scale installers reacted by pivoting toward cash and loans (Litvak 2015). The platform's installers appear to have reacted similarly, by shifting rapidly toward cash offers in 2015 followed by loans in 2016.

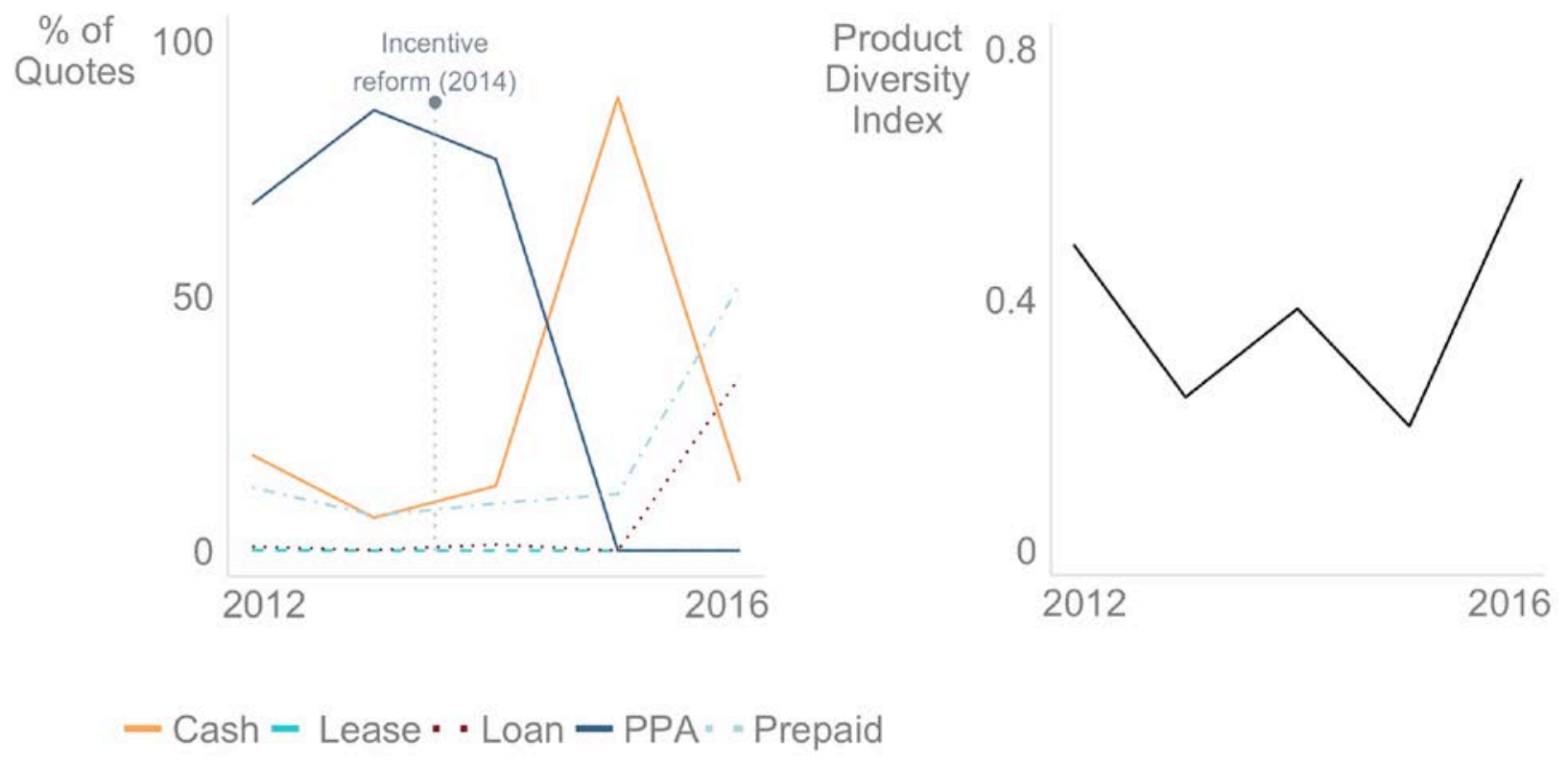

Figure 11. Trends in PV product portfolios in Colorado

Product diversity was relatively high in Colorado throughout the study period (Figure 11, right pane). Unlike in other states, prepaid products were relatively popular in Colorado, especially in 2016 when they accounted for about $52 \%$ of all quotes in Colorado. Loans were relatively uncommon in Colorado until 2016, when they accounted for about 34\% of quotes, the highest penetration of loans into any state in any year of the data set. The move toward loans may reflect the attempts of installers to find new ways to capitalize on the relatively generous incentives for customer-owned systems in Colorado.

\subsubsection{Connecticut}

The platform's installers in Connecticut exhibited substantial changes in their product portfolios over time, with TPO products initially rising in prevalence from 2012 to 2014, declining in 2015, and then increasing to about $100 \%$ of all quotes in 2016 (Figure 12). 


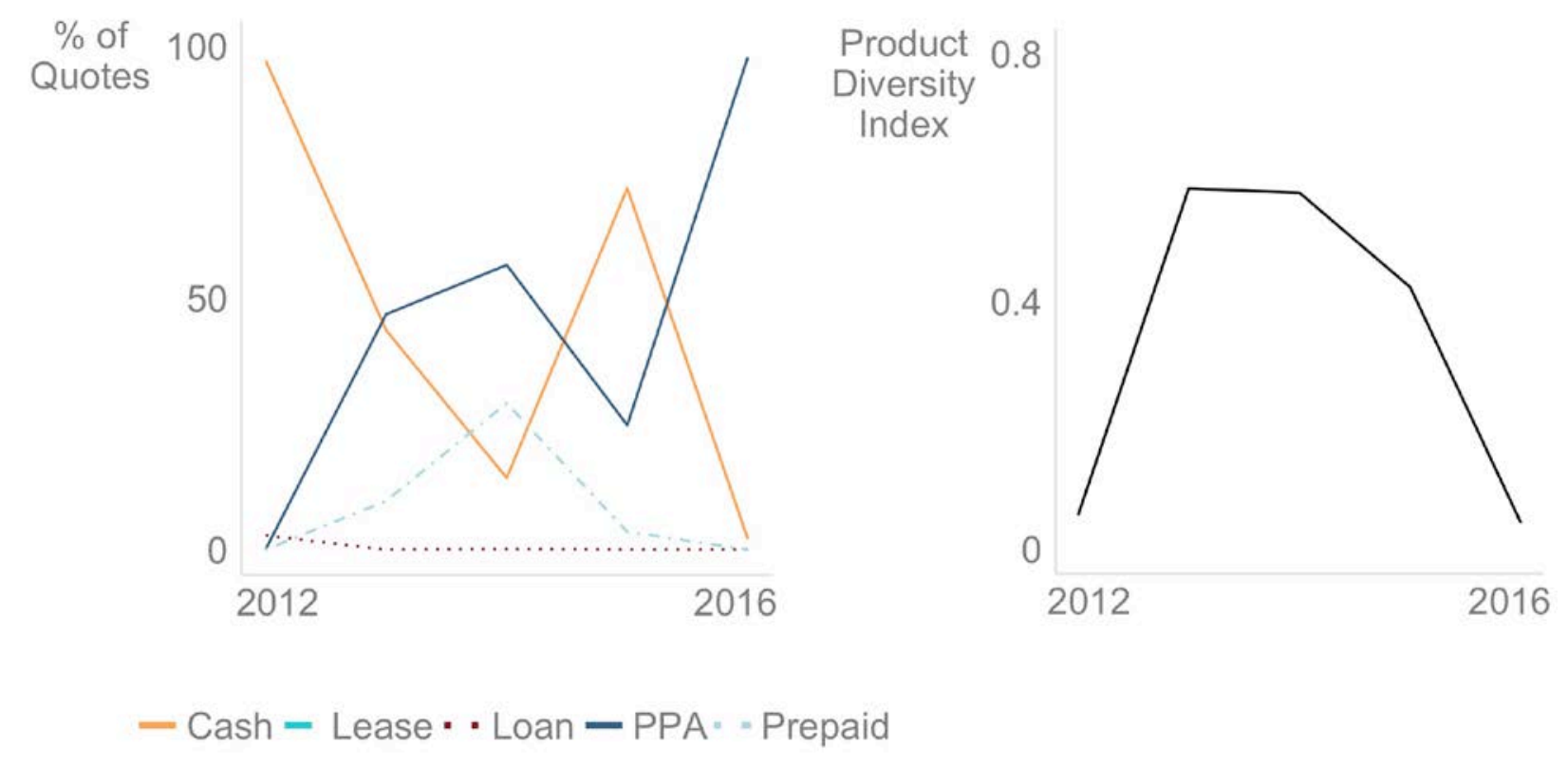

Figure 12. Trends in PV product portfolios in Connecticut

The seemingly erratic trends in the Connecticut PV product portfolio may reflect trends in the state's complex PV incentive structure. In Connecticut, customer-owned systems are eligible for rebates worth $\$ 0.46 / \mathrm{W}$ for up to $10 \mathrm{~kW}$ installed, while TPO systems are eligible for productionbased incentives worth $\$ 0.035 / \mathrm{kWh}$ for up to $20 \mathrm{~kW}$ installed. Further, for a brief period from 2014 to 2015, Connecticut PV systems were eligible for the CT Solar Lease (Renny and Malpani 2018). The CT Solar Lease connected prospective customers with eligible lenders to offer leases with immediate savings (Renny and Malpani 2018). The CT Solar Lease program reached capacity in July 2015. Connecticut PV customers were then eligible for low-interest loans through the Connecticut Green Bank's Smart-E loan program.

The move away from PPAs from 2014 to 2015 and then back toward PPAs from 2015 to 2016 may reflect installer strategies on the platform in reaction to Connecticut incentives. PPAs and prepaid products may have been uncompetitive with the CT Solar Lease, which could have driven the rapid shift away from these products from 2014 to 2015. Similarly, cash and loan offers may be uncompetitive with the Smart-E loan, which could have driven the shift back toward PPAs as the incentive structure shifted from the CT Solar Lease to the Smart-E loan.

The temporary increase in prepaid offers in 2014 may have been driven in part by a single installer's regional Solarize campaigns, which we discuss in Section 4.2.7.

\subsubsection{Hawaii}

The platform's installers in Hawaii primarily offered cash quotes from 2012 to 2015 (Figure 13), likely reflecting the highly favorable economics of customer ownership in Hawaii, where customers pay the highest volumetric electricity rates in the country. However, Hawaii effectively ended net metering at the end of 2015. The sharp increase in cash offers in 2015 may represent a rush of installers selling customer-owned systems before the net-metering cliff. The end of net metering and uncertainty about future rate reforms reduced tax-equity investor confidence in Hawaii PV investments (Litvak 2015). Given uncertainty about future PPA or 
lease payments, tax-equity investors pushed to offer prepaid products in Hawaii after the end of net metering (Litvak 2015). Installers on the platform responded: prepaid offers rose from about $16 \%$ of quotes in 2015 to $63 \%$ of quotes in 2016 . At the same time, PPAs rose from about $10 \%$ of quotes in 2015 to $27 \%$ of quotes in 2016 . These trends suggest that many, but not all, installers reacted to tax-equity investor concerns. Specifically, as we show in Section 4.3, it appears that new installers were more likely to react to the demands of tax-equity investors and pivot toward prepaid products.

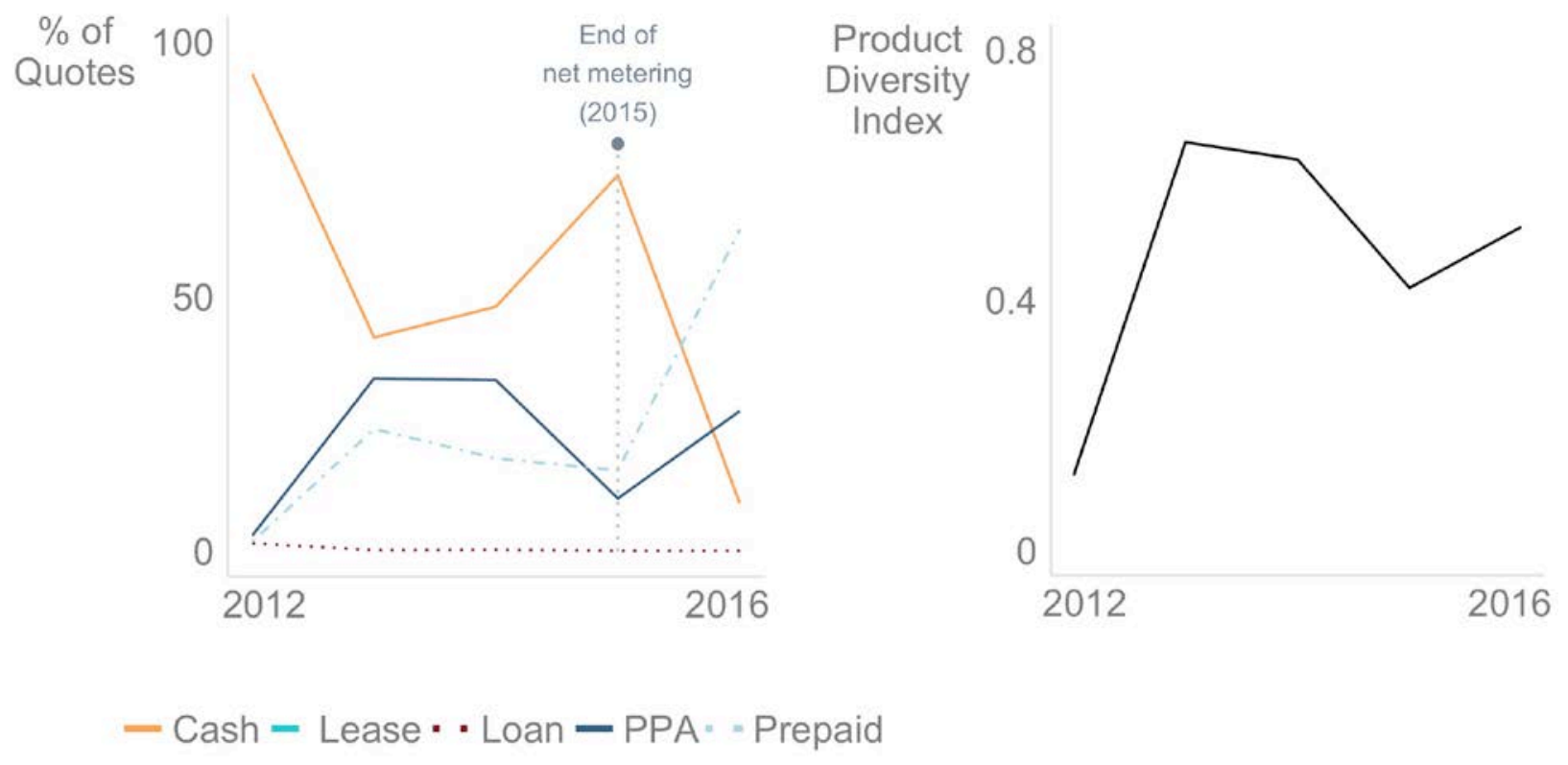

Figure 13. Trends in PV product portfolios in Hawaii

\subsubsection{Louisiana}

Thirty-one installers submitted 1,479 quotes via the platform in Louisiana from 2012 to 2016, allowing us to analyze this relatively small and understudied market. Installers offered almost exclusively cash quotes from 2012 to 2014 before shifting toward leases and prepaid products in 2015 and 2016 (Figure 14). Louisiana is the only state in the analysis where product diversity consistently increased year over year (Figure 14, right pane). Increasing product diversity in the state may reflect the maturation of the market. As Louisiana's installers and customers became more familiar with PV, installers may have become more willing to venture into new products and explore leases and prepaid options on behalf of their customers. 


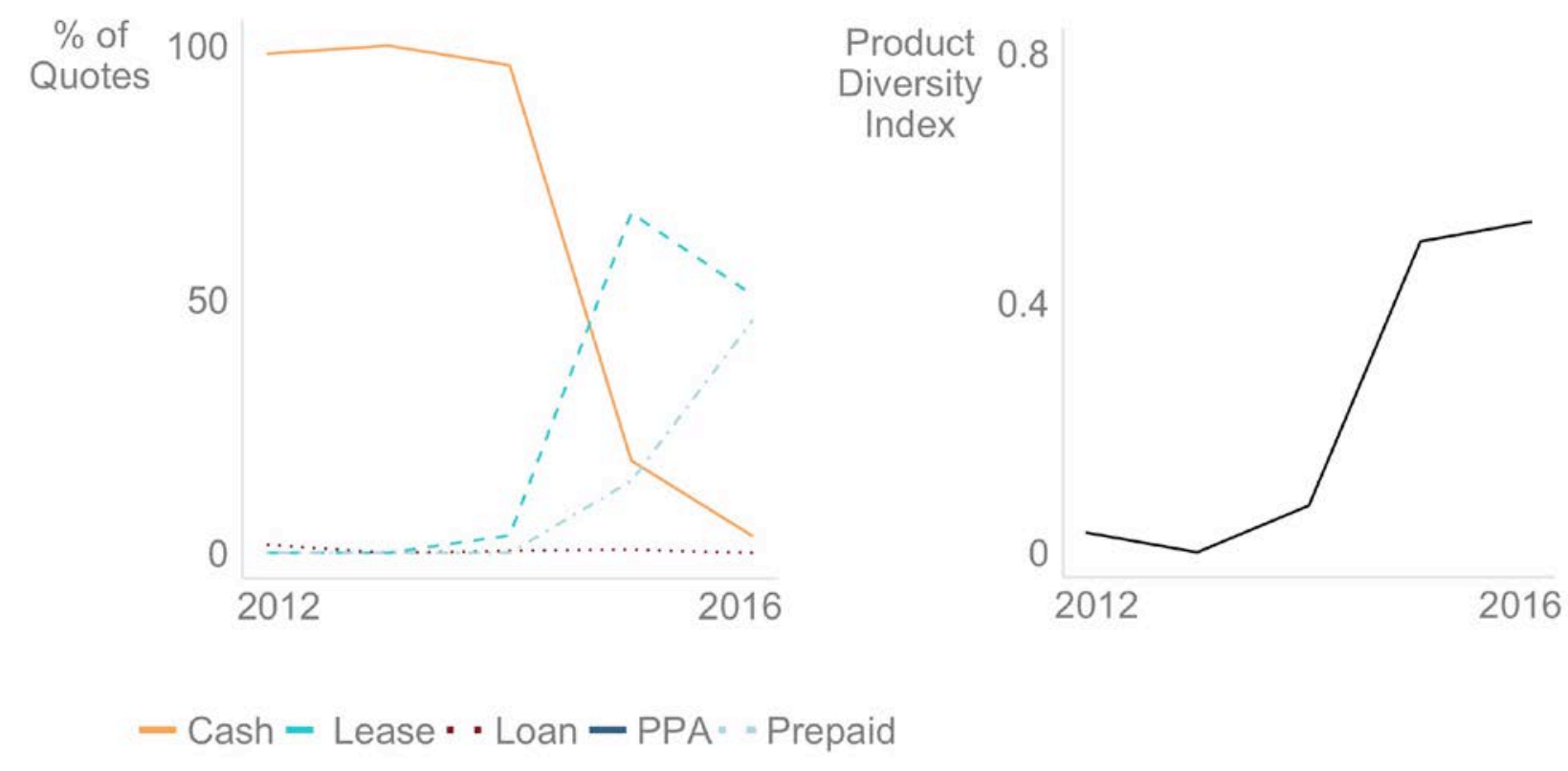

Figure 14. Trends in PV product portfolios in Louisiana

Two of Louisiana's largest utilities reached net-metering caps by the end of 2015. Subsequent legislation clarified that new customers beyond these caps would be net metered at the utility's avoided cost rather than the full retail rate (DSIRE 2018). These reforms may have undermined the value proposition of system ownership and contributed to the ongoing decline of cash offers from 2015 to 2016. As in Hawaii, tax-equity investors may have pushed for more prepaid offers to hedge against the net-metering changes and uncertainty about future rate reforms. Prepaid products increased from 14\% of quotes in 2015 to $46 \%$ of quotes in 2016 in Louisiana.

\subsubsection{Massachusetts}

In Massachusetts, the platform's installers mostly offered cash quotes from 2012 to 2015 (Figure 15), possibly reflecting installers' strategic reactions to customer preferences. Massachusetts customers historically showed a preference for customer ownership, possibly due to a relatively wealthy and educated customer base (Litvak 2015; Rai et al. 2016). National-scale TPO installers entered Massachusetts in 2015 (Litvak 2016), educating the customer base about TPO products, especially PPAs. The entry of the national-scale TPO installers may have driven more installers to offer PPAs on the platform: the PPA share of quotes jumped from 9\% in 2015 to $94 \%$ in 2016. 


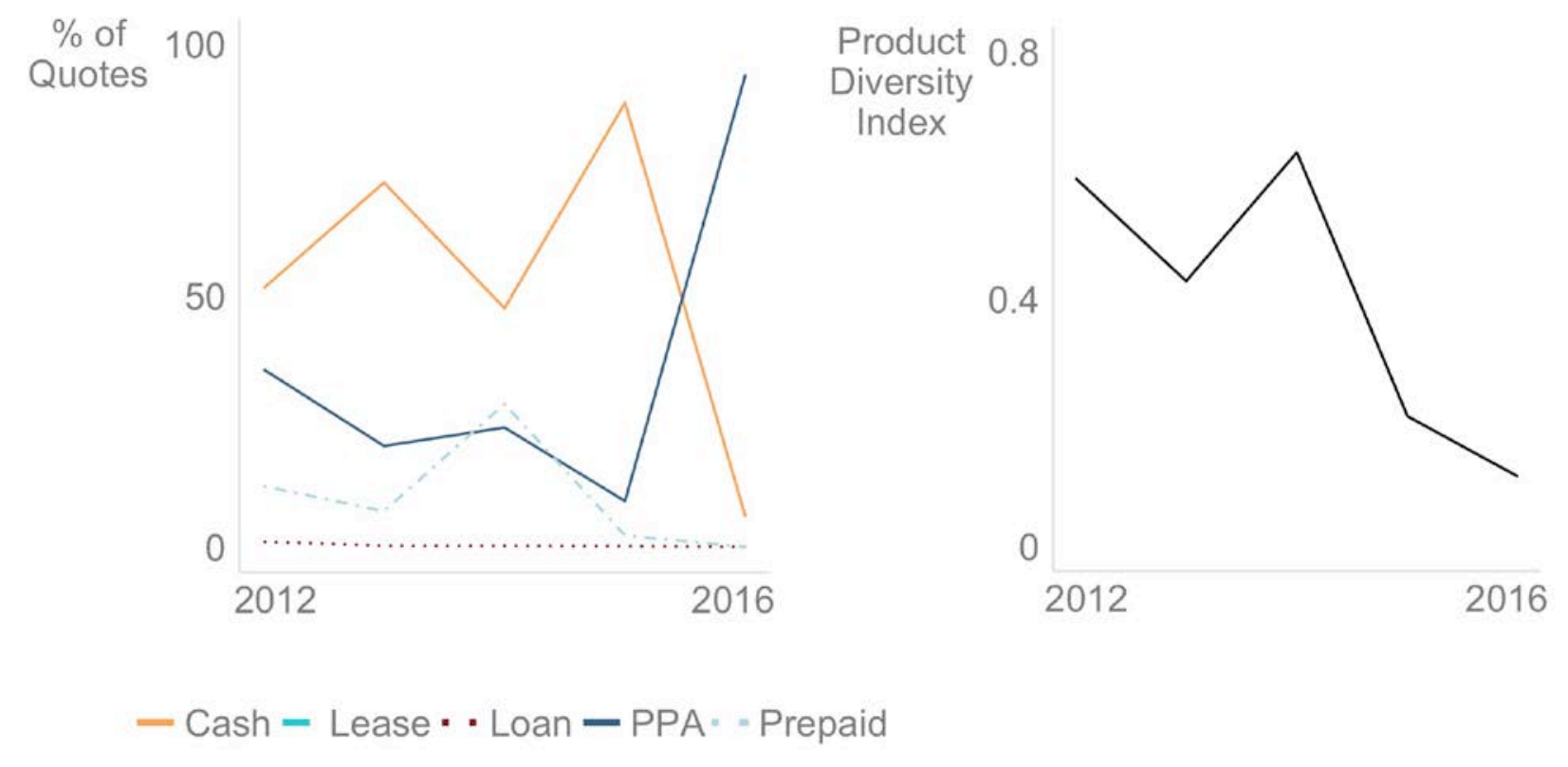

Figure 15. Trends in PV product portfolios in Massachusetts

The brief spike in prepaid products in 2014 - also present in Connecticut and New Jersey - was mostly driven by a single installer that shifted heavily toward prepaid offers in that year. The installer was involved in several Solarize programs in the Northeast at the time. In a Solarize program, a community entity works with a single installer or small group of installers to procure PV on behalf of numerous customers. Although we cannot confirm our hypothesis based on the data, we believe that the installer used the platform to manage prepaid leases for the Solarize campaigns in 2014. Removing the installer in question from the data set effectively eliminates the temporary increase in prepaid offers in 2014 in Connecticut, Massachusetts, and New Jersey.

\subsubsection{Nevada}

In Nevada, the platform's installers offered cash options nearly exclusively from 2012 to 2014 before shifting to PPAs in 2015 (Figure 16). The pivot to PPAs on the platform correlated with similar strategies implemented by national-scale TPO installers. As a way to gain market share and capitalize on PV rebates, national-scale installers increased TPO volumes rapidly in Nevada in 2015. The expansion of national-scale TPO installers may have educated Nevada customers about PV in general and sparked interest in TPO. Installers on the platform appear to have reacted in kind: they offered no PPAs in 2014, but PPAs accounted for 64\% of quotes in 2015. Nevada eliminated net metering at the end of 2015. As in Hawaii, the end of net metering and uncertainty about future rate reforms may have shaken investor confidence in PV investments in the state. In contrast with Hawaii's experience, however, Nevada installers did not react by shifting toward prepaid offers but rather by shifting back toward cash. 


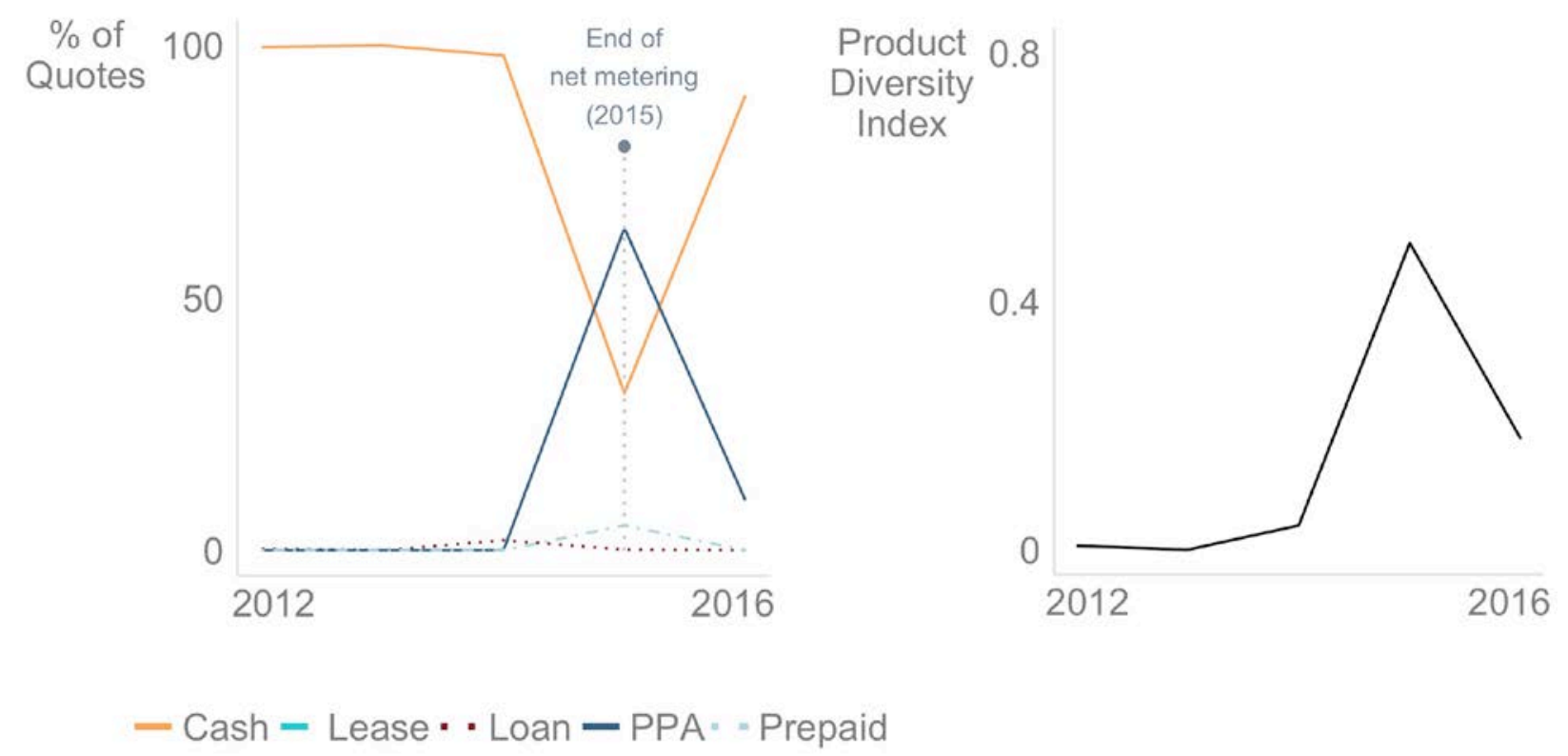

Figure 16. Trends in PV product portfolios in Nevada

\subsubsection{New Jersey}

In contrast to nearby New York and Massachusetts, the platform's installers primarily offered PPAs in New Jersey in 2012 and 2013 (Figure 17). The prevalence of TPO strategies in New Jersey may stem from the state's solar renewable energy certificate (SREC) market. In New Jersey, PV system output can be sold into SREC markets at prices around $\$ 100-\$ 300 / \mathrm{MWh}$. However, SREC prices have been historically volatile. By choosing TPO rather than ownership, PV customers can ensure a more stable value stream and outsource some SREC risk to thirdparty system owners (Litvak 2015; Mond 2018). Unlike the New Jersey market outside the platform, PPA offers on the platform dropped in 2014 and 2015 before rebounding in 2016. The drop in PPAs in 2014 may have been driven in part by a single installer's shift toward prepaid offers, which we discuss in our analysis of Massachusetts (Section 4.2.7). The shift toward cash in 2015 may be a data anomaly: only 489 quotes were submitted in New Jersey in 2015, compared to 2,795 quotes in 2014 and 14,335 quotes in 2016. 


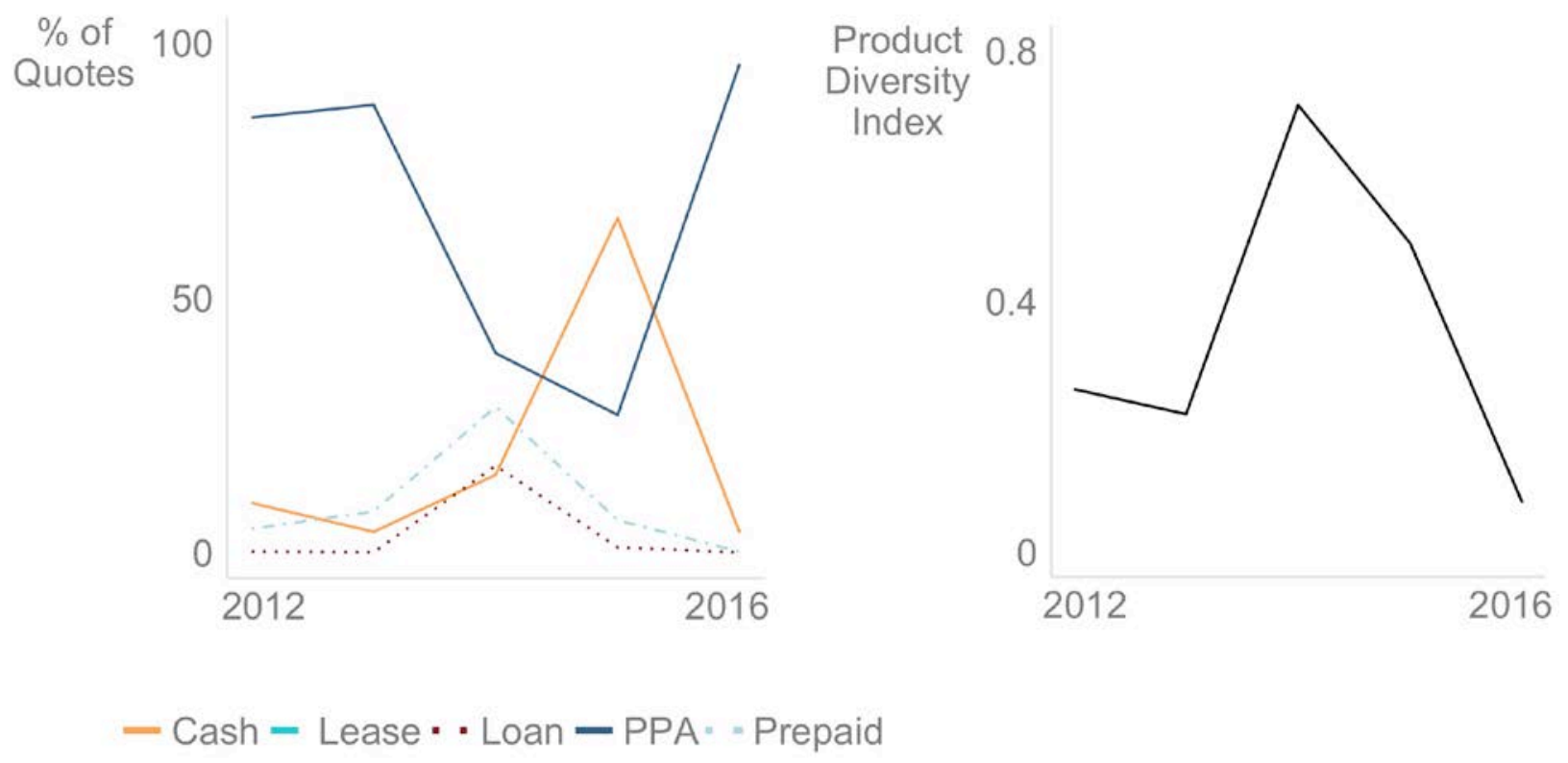

Figure 17. Trends in PV product portfolios in New Jersey

\subsubsection{New York}

Cash offers generally dominated on the platform from 2012 to 2015 (Figure 18), possibly reflecting installer response to customer preferences for system ownership. In January 2013, New York implemented a tax credit for TPO systems that allowed lessees and PPA offtakers to claim $25 \%$ of the value of their PV payments as a tax credit. Installers on the platform initially responded by shifting to leases in 2013 and 2014, before shifting to PPAs in 2015 and 2016.

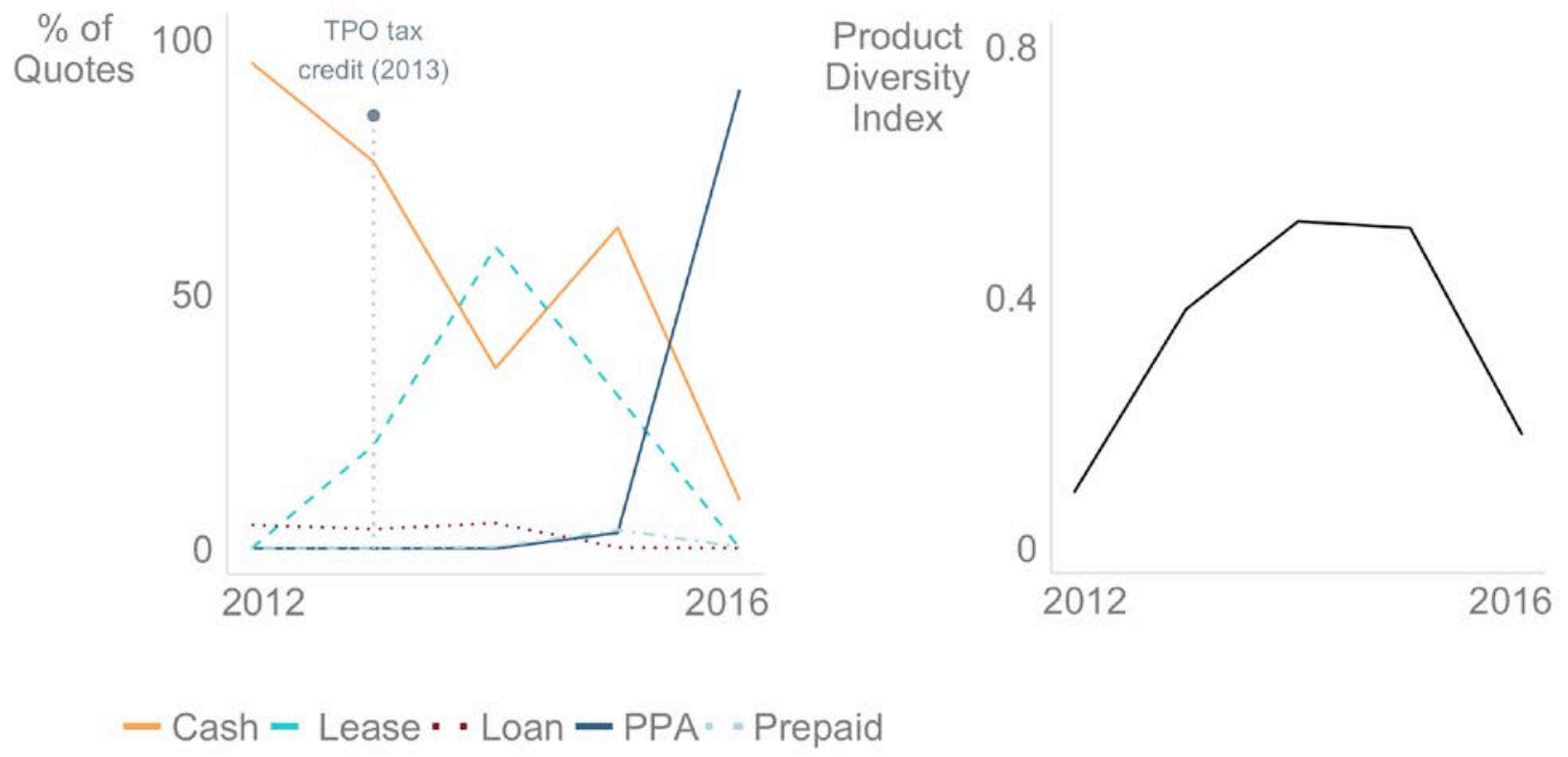

Figure 18. Trends in PV product portfolios in New York 


\subsubsection{Summary of Findings from State-Level Analyses}

Our analysis of installer quoting activity on the platform provides evidence that installers react strategically to market dynamics and policies by modifying product portfolios. Specifically:

- Installers modified product portfolios in response to policy changes. In several cases, installers appear to have reacted strategically to policy reforms. For instance, installers in New York shifted toward leases and PPAs following the implementation of an incentive for TPO systems.

- Installers may have reacted to investor concerns. In Hawaii, installers increased the use of prepaid offers in 2016, the same year that tax-equity investors pushed for more prepaid products as a way to hedge against uncertain future rate reforms.

- The strategies of national-scale installers may have influenced small and mid-scale installer strategies. In several cases, TPO trends on the platform correlated with similar trends for product offerings by national-scale TPO installers. For instance, installers in Massachusetts shifted toward TPO around the same time that national-scale TPO installers entered the state, and a ramp-up of TPO quotes on the platform in Nevada correlated with a similar ramp-up of national-scale TPO provider activity. Small and midscale installers might mimic the strategies of national-scale installers. Alternatively, the presence of national-scale installers might educate customers and increase interest in TPO products, which may drive small and mid-scale installers to shift toward TPO in order to satisfy customer demands.

\subsection{Installer Strategy: Reactions of Incumbent Installers or the Result of Installer Turnover?}

Up to this point, our analyses have encompassed all installers in given markets. However, the shifts in the platform's product portfolios could result from an existing group of installers making strategic changes and/or new installers (possibly with new strategies) entering the market and old installers (with old strategies) exiting it. About 7\% of the platform's installers were existing installers or incumbents that submitted at least one quote every year during the study period (2012-2016); they accounted for about $38 \%$ of platform quotes. The remainder of the platform's installers were transients that entered the platform after 2012 or exited the platform before 2016. In this section, we explore the degree to which trends in product diversity and customer choice were driven by the strategic behavior of incumbents versus transients, which could provide deeper insight into how PV markets evolve.

On the platform, incumbents gradually shifted toward cash offers, with cash composing about $40 \%$ of incumbent quotes in 2012 and $80 \%$ in 2016 (Figure 19). In contrast, transients shifted away from cash offers and toward PPAs throughout the study period. Transients were generally more likely than incumbents to offer the less common lease, prepaid, and loan products. This could reflect that transient installers undergo a learning process when entering a new market and testing new products, which can enhance customer choice but also possibly lead to customer confusion. 


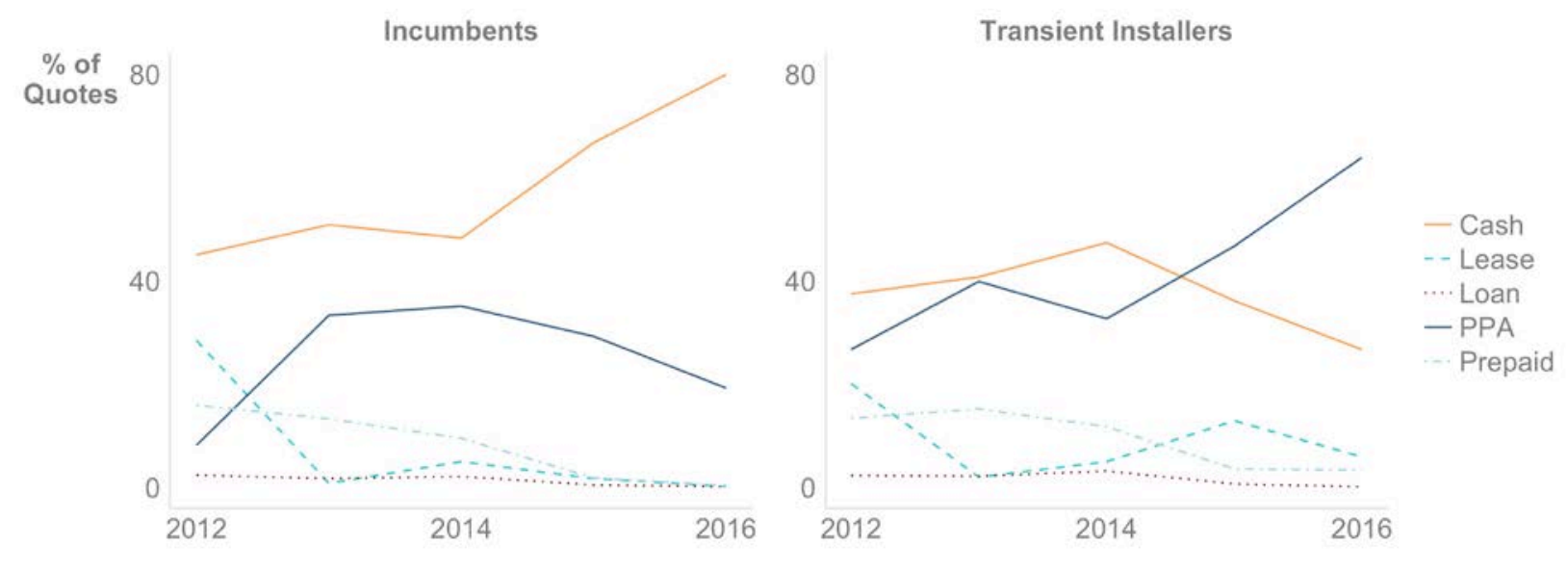

Figure 19. Distributions of product types over time for incumbents and transients

The diversity of the incumbent installer group's product portfolio declined over time as incumbents increasingly shifted toward cash offers (Figure 20). The diversity of the transient installer product portfolio also declined over time as transients shifted toward PPAs, but transients offered a more diverse product portfolio than incumbents throughout the study period, particularly in 2016 .

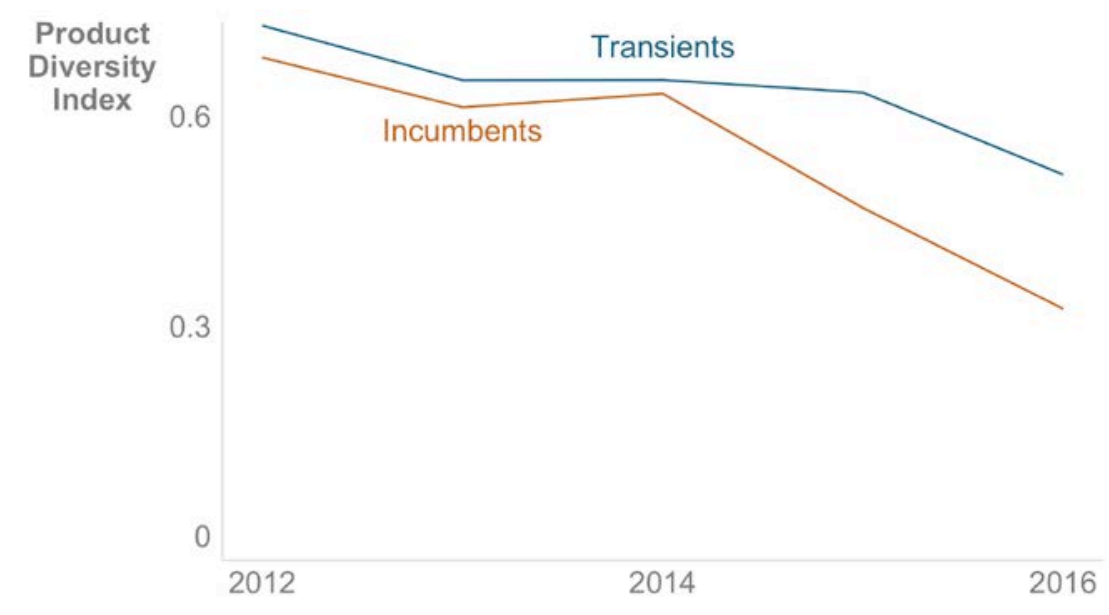

Figure 20. Product diversity over time for incumbents and transients

The reduction in product diversity among incumbents from 2014 to 2016 may reflect some degree of path dependence: installers may "lock in" to a specific strategy and maintain that strategy, even if changing market conditions would merit a strategic shift. In fact, $95 \%$ of incumbents offered the same product in more than half of their quotes, $78 \%$ of incumbents offered the same product in more than $90 \%$ of their quotes, and $44 \%$ of incumbents offered the same product in all their quotes. In other words, these installers exhibited strong preferences for a specific product, despite the general availability of alternative options on the platform. Many incumbents appear to have locked-in to a business practice of using the platform solely as a customer relationship management tool rather than as an opportunity to acquire customers via attractive financing products. In 2016, $91 \%$ of incumbents offered only cash on the platform, compared to $55 \%$ of incumbents offering only cash in 2012 . These results provide some 
evidence that, at least on the platform, changes in product portfolios and customer choice are driven by the entry and exit of installers rather than strategic shifts by existing installers.

In Section 4.2, we identify several state-level policy events that correlate with apparent changes in installer strategies on the platform. In the remainder of this section, we explore whether incumbents and transients reacted differently to key policy events in Arizona, Hawaii, and New York.

In Arizona, installers shifted toward leases over time, particularly after utility rate reforms in 2015 that undermined the economics of customer-owned systems (see Section 4.2.1). Figure 21 shows how the shift toward TPO was driven almost entirely by transients. In contrast, incumbent installers moved increasingly toward cash or loans, offering no TPO quotes in 2016.

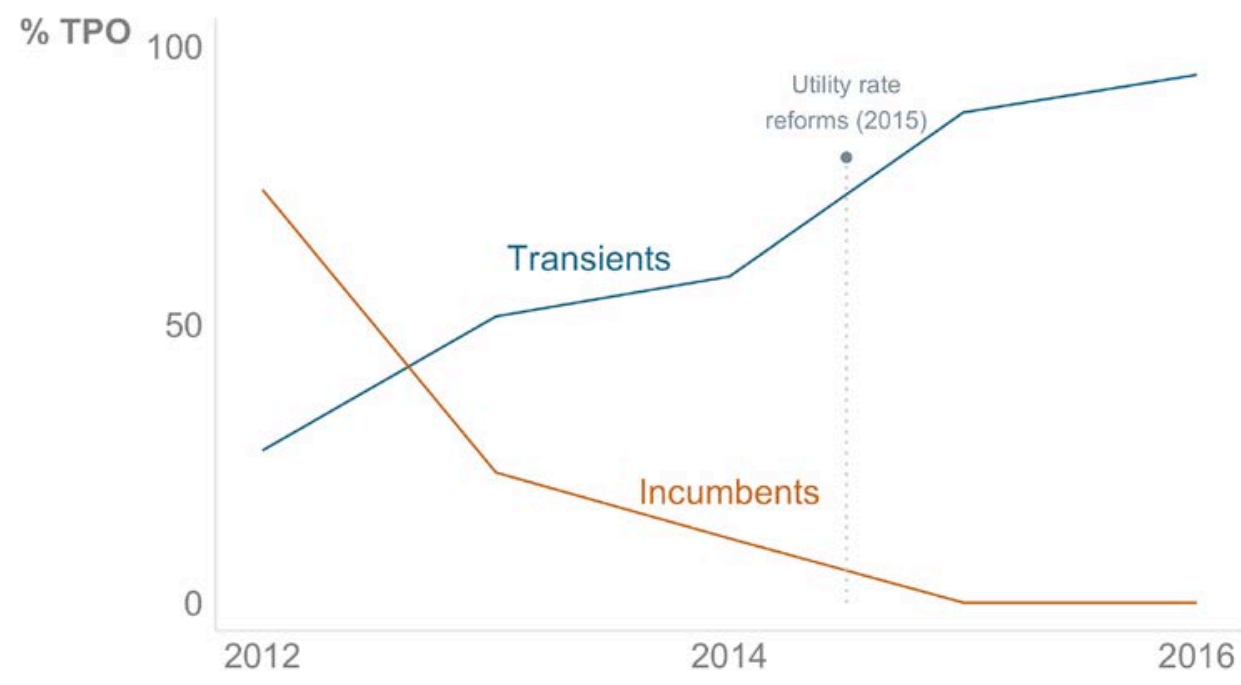

Figure 21. Percentage of quotes using TPO by incumbent and transient installers in Arizona

In Hawaii, installers shifted toward prepaid offers following the end of net metering in 2015 (see Section 4.2.5). This shift may have been a response to the reticence of investors to enter into PPAs, given the lack of net metering and uncertainty about future rate reforms (Litvak 2015). The shift toward prepaid offers in Hawaii was driven entirely by transients (Figure 22). From 2014 to 2016, transients increased the prepaid share of their quotes from 19\% to $67 \%$, compared to a drop from $15 \%$ to $0 \%$ among incumbent installers. 


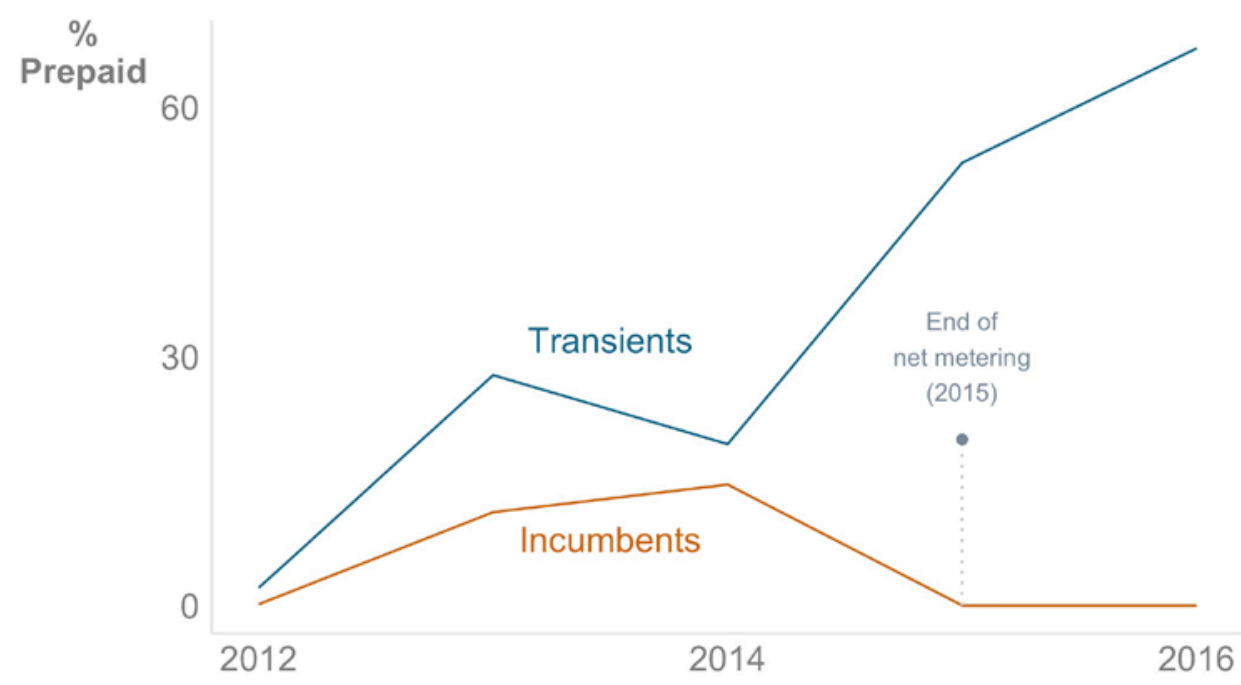

Figure 22. Percentage of quotes using prepaid TPO by incumbent and transient installers in Hawaii

New York implemented new rebates for TPO systems that became effective on January 1, 2013. These rebates may have contributed immediately to the sharp increase in leases and PPAs in New York from 2013 through 2016 (see Section 4.2.10). In contrast to the outcomes in Arizona and Hawaii, the shift toward TPO in New York occurred sooner and more dramatically among incumbents rather than transients (Figure 23). The percentage of incumbent TPO quotes jumped from less than $1 \%$ in 2013 to $86 \%$ in 2014 . Transients shifted toward TPO more gradually, ultimately offering TPO in $92 \%$ of quotes in 2016.

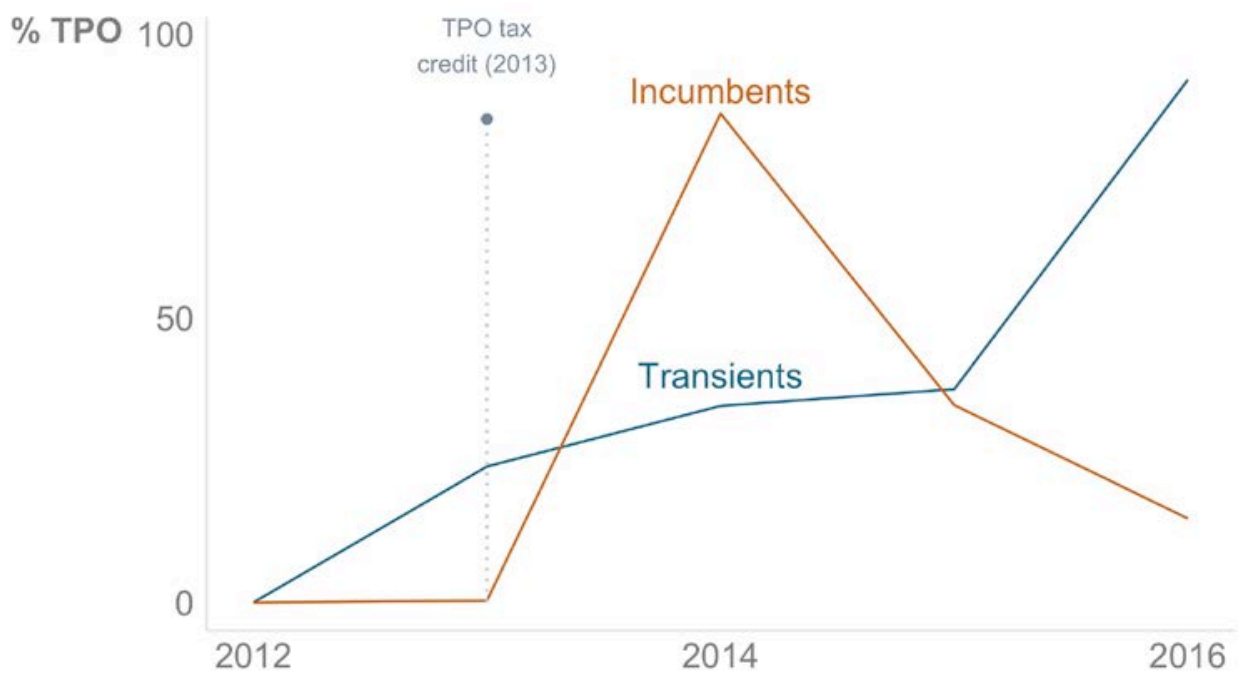

Figure 23. Percentage of quotes using TPO by incumbents and transients in New York 


\section{Discussion}

Our analysis shows that small and mid-scale PV installers leveraged a third-party financing platform to offer a range of financing products, including TPO products. In doing so, these installers appeared to modify their product offerings in response to their specific contexts. In fact, the composition of products offered by these installers varied so much by year and by state that no clear national trend is discernible. From 2012 to 2016, product diversity declined in some states and rose in others, typically with distinct year-to-year diversity ups and downs occurring within that period. TPO products became the dominant offerings over time in some states, whereas cash and/or loans became dominant in others, again with multiple, often dramatic oscillations. Within the TPO category, the types of products offered varied substantially over time and by state.

The year- and state-specific trends observed suggest the influence of variable supply- and demand-side drivers on the product portfolios of the platform's installers. In several states, installers apparently modified their portfolios in response to state policy changes that favored some financing products over others. In some cases, this connection between policies and portfolios likely was mediated by investors. For example, tax-equity investor interest in prepaid products in Hawaii and Louisiana - as a hedge against future rate uncertainty - may have resulted in installer portfolio shifts toward prepaid products.

The impacts on customer choice of these installer responses to policy were complex. Most obviously, by subjecting residential and private-entity PPAs to utility regulation, Arizona precluded installers from offering that option. Cumulatively across the entire study period (2012-2016), PPAs were the most frequently offered TPO product in each of the eight states that offered them, so restricting their use may have been a meaningful constraint on customer choice. In other cases, product diversity decreased or increased after policy enactment, with varying lag times and complications resulting from ensuing market developments. Regardless of the absolute changes in product diversity resulting from state policies, the willingness and ability (through the platform) of these small and mid-scale installers to tailor their offerings to changing policy environments may have increased the attractiveness of whatever choices customers ultimately had within those environments.

The financing products offered by national-scale installers and public entities also appeared to influence the portfolios of the platform's installers. In some states, the platform's installers followed trends set by national-scale installers, for example, by expanding TPO offerings simultaneously with the market entry of national-scale TPO installers. In many cases, smallerscale and national installers interact with the same customers. As national installers stimulate customer demand through educational and promotional activities, smaller-scale installers may need to mimic their sales pitches and product offerings to remain competitive with customers. Conversely, by continuing to increase their PPA offerings through 2016, the platform's installers in California deviated from the strategies of national installers, which shifted toward cash and loans. Similarly, the platform's installers in Connecticut may have shifted their portfolios in response to a publicly supported PV lease program (by making more cash offers than PPA offers) during one period and a publicly supported loan program (by making more PPA offers than cash offers) during another. 
Again, the impacts on customer choice of these installer responses were multifaceted. Where the platform's installers followed national-scale installer trends, they might have reduced the total diversity of product choices available to customers (from small, mid-scale, and large installers combined), regardless of the diversity shift of small and mid-scale installers alone. However, where the platform's installers deviated from market trends, they may have increased customer choice, even if the diversity of small and mid-scale installers alone decreased. For example, the large installer move away from TPO products in California might have been shaped by shareholder demands for increased profitability and cash positions, creating a disconnect between the portfolios of those installers and customer demand for financing products - and thus might have created a niche that the platform's installers could fill to the benefit of customer choice. Similarly, when the platform's installers in Connecticut changed their offerings in alignment with the start and end of public PV financing programs, they complemented the total financing product diversity and thus increased customer choice.

Of course, customer choice encompasses more than just the diversity of financing products available. If, for example, a customer receives a PPA offer from a national-scale installer and one from a small installer, that customer has an additional specific choice (likely with different total cost, financing terms, for example) that they would not have had if they received only the national-scale installer's offer. In that sense, financing platforms - which expand the financing options of small and mid-scale installers - inherently expand customer choice. The demonstrated responsiveness of these platform-enabled smaller installers to changing market and policy contexts further enhances their ability to satisfy otherwise-unmet demand for diverse PV financing products.

Finally, at a broad level, the tendency of incumbent installers to lock in to specific product offerings on the platform suggests a potential supply-side limitation on customer choice while highlighting the role of transient installers in expanding choice. Among incumbents, 95\% offered the same product in more than half of their quotes, $78 \%$ offered the same product in more than $90 \%$ of their quotes, and $44 \%$ offered the same product in all their quotes. Thus, shifts in financing product availability were driven mostly by installer turnover - as transient installers came in with new strategies - rather than by strategic shifts among incumbent installers. This trend could result from the platform's policies. The platform requires its installer partners to invest time and money in training programs to qualify for sales access to each financing product in each state. As new installers enter a market, they may make this investment to provide financing products that align with current policy and market conditions. However, incumbent installers may hesitate to make additional investments once they have already established their niche. Although this specific situation is unique to the platform, similar costs must be incurred when other installers invest in developing new products. This finding generally suggests that customers in regions with primarily static incumbent installers may have less access to finance options that align with changing market conditions than customers in regions with frequent installer turnover. That said, there is a trade-off between customer choice and trust, and customers in markets with high installer turnover may hesitate to work with new installers that have not yet established a positive reputation. 


\section{References}

Barbose, G. and N. Darghouth. 2017. Tracking the Sun 10: The Installed Price of Residential and Non-Residential Photovoltaic Systems in the United States. Berkeley, CA: Lawrence Berkeley National Laboratory.

Brown, L. 1981. Innovation Diffusion, London: Methuen.

Dasgupta, S., S. Siddarth, J. Silva-Risso. "To Lease or to Buy? A Structural Model of a Consumer's Vehicle and Contract Choice Decisions." Journal of Marketing Research. 44(2007):490-502.

Davidson, C., D. Steinberg, and R. Margolis. 2015. "Exploring the Market for Third-PartyOwned Residential Photovoltaic Systems: Insights from Lease and Power-Purchase Agreement Contract Structures and Costs in California." Environmental Research Letters 10:024006.

Drury, E., M. Miller, C. Macal, D. Graziano, D. Heimiller, J. Ozik, and T.D. Perry. 2012. “The Transformation of Southern California's Residential Photovoltaics Market through Third-Party Ownership." Energy Policy 42:681-690.

DSIRE (Database of State Incentives for Renewables \& Efficiency). 2018. http://www.dsireusa.org/.

Kann, S. 2013. U.S. Residential Solar PV Financing: The Vendor, Installer and Financier Landscape, 2013 - 2016. GTM Research.

Kollins, K., B. Speer, and K. Cory. 2010. Solar PV Project Financing: Regulatory and Legislative Challenges for Third-Party PPA System Owners. NREL/TP-6A2-46723. Golden, CO: NREL.

Litvak, N. 2014. U.S. Residential Solar Financing 2014-2018. GTM Research

Litvak, N. 2015. U.S. Residential Solar Financing 2015 - 2020. GTM Research.

Litvak, N. 2016. U.S. Residential Solar Financing 2016-2021. GTM Research.

MIT (Massachusetts Institute of Technology). 2015. The Future of Solar Energy. MIT.

Mond, A. 2017. U.S. Residential Solar Finance Update, H2 2017. GTM Research.

Mond, A. 2018. Bringing Scale, Profitability and Value to the Residential Solar Market. GTM Research.

O’Shaughnessy, E. 2018. The Evolving Market Structure of the U.S. Residential Solar PV Installation Industry, 2000-2016. NREL/TP-6A20-70545. Golden, CO: NREL.

Rai, V., and B. Sigrin, B. 2013. "Diffusion of Environmentally-Friendly Energy Technologies: Buy versus Lease Differences in Residential PV Markets." Environmental Research Letters 8(1): 14022 . 
Rai, V., D.C. Reeves, and R. Margolis. 2016. "Overcoming Barriers and Uncertainties in the Adoption of Residential Solar PV.” Renewable Energy, 89:498-505.

Reeves, D. C., V. Rai, and R. Margolis. 2017. "Evolution of Consumer Information Preferences with Market Maturity in Solar PV Adoption." Environmental Research Letters 12(7):74011.

Renny, J. and S. Malpani. 2018. Case Study 2: CT Solar Lease 2. Yale Center for Business and the Environment.

Speer, B. 2012. Residential Solar Photovoltaics: Comparison of Financing Benefits, Innovations, and Options. NREL/TP-6A20-51644. Golden, CO: NREL. 